\title{
Design, synthesis and anticancer properties of isocombretapyridines as potent colchicine binding site inhibitors
}

\author{
Wen Shuai ${ }^{\text {a }}$, Xinnan $\mathrm{Li}^{\text {a }}$, Wenlong $\mathrm{Li}^{\text {a }}$, Feijie $\mathrm{Xu}{ }^{\text {a }}$, Lixue Lu ${ }^{\text {a }}$, Hong Yao ${ }^{\text {a }}$, Limei \\ Yang a , Huajian Zhu ${ }^{\text {a }}$, Shengtao $\mathrm{Xu}^{\text {a, }}{ }^{*}$, Zheying Zhu ${ }^{\mathrm{b}}$, Jinyi $\mathrm{Xu}{ }^{\mathrm{a}}$ * \\ ${ }^{a}$ State Key Laboratory of Natural Medicines and Department of Medicinal Chemistry, China \\ Pharmaceutical University, 24 Tong Jia Xiang, Nanjing 210009, P. R. China. \\ ${ }^{\mathrm{b}}$ Division of Molecular Therapeutics \& Formulation, School of Pharmacy, The University of \\ Nottingham, University Park Campus, Nottingham NG7 2RD, U. K.
}

\begin{abstract}
A series of novel isocombretapyridines were designed and synthesized based on a lead compound isocombretastatin A-4 by replacing 3,4,5-trimethoxylphenyl with substituent pyridine nucleus. The MTT assay results showed that compound 20a possessed the most potent activities against all tested cell lines with $\mathrm{IC}_{50}$ values at nanomolar concentration ranges. Moreover, 20a inhibited tubulin polymerization at a micromolar level and also displayed potent anti-vascular activity in vitro. Further mechanistic studies were conducted to demonstrate that compound 20a could bind to the colchicine site of tubulin, and disrupted the cell microtubule networks, induced G2/M phase arrest, promote apoptosis and depolarized mitochondria of K562 cells in a dose-dependent manner. Notably, 20a exhibited more potent tumor growth inhibition activity with $68.7 \%$ tumor growth inhibition than that of isoCA-4 in $\mathrm{H} 22$ allograft mouse model without apparent toxicity. The present results suggest that compound 20a may serve as a promising potent microtubule-destabilizing agent candidate for the development of therapeutics to treat cancer.
\end{abstract}

Key words: isocombretapyridines, tubulin inhibitors, colchicine binding site, anti-vascular, antitumor.

\section{Introduction}

Microtubules, which are composed of $\alpha$ - and $\beta$-tubulin heterodimers and serve as the major component of cytoskeleton, have essential roles in several biological functions, such as cell proliferation, shape maintenance, intracellular trafficking, 
migration, cell division and mitosis [1-3]. Microtubules are in the state of dynamic equilibrium in which alternative cycling of microtubule assembly and disassembly take place. Accordingly, interfering with microtubule dynamic equilibrium has emerged as an effective strategy for the treatment of cancer [4-7]. The agents interfering with microtubule dynamics are classified into two main categories: microtubule-stabilizing agents and microtubule-destabilizing agents [8]. Microtubule-stabilizing agents, which can promote microtubule polymerization, usually bind to the taxane binding site while microtubule-destabilizing agents, which can promote microtubule depolymerization, usually bind to vinca alkaloid or colchicine binding sites $[9,10]$. Compared with other sites binders, inhibitors binding to colchicine binding site have several advantages, such as simpler structures, improved aqueous solubility, reduced toxicity, additional anti-vascular activity and multidrug resistance (MDR) effects $[11,12]$. Therefore, in recent decades, considerable research efforts have been devoted to developing the agents targeting colchicine binding site [13-15].

Combretastatin A-4 (CA-4, 1, Figure 1A), a representative colchicine binding site inhibitor derived from the African bush willow tree Combretum caffrum, displayed potent anticancer and anti-vascular activity [16]. CA-4 has become a structural model for designing new analogs due to its potent anti-vascular and anticancer profiles. However, CA-4 suffers from chemical instability via easy isomerization to the less active but thermodynamically more stable $E$-isomer during storage, administration and metabolism [17]. The discovery of new CA-4 analogs have circumvented the stability problem, such as isocombretastatin A-4 (isoCA-4, 2) [18] and Phenstatin (3, Figure 1A) [19]. IsoCA-4 with 1,1-diarylethylene scaffold possesses similar biological properties as CA-4 but it is more chemically and metabolically stable [18].

Nitrogenous heterocycles, such as quinazoline, quinoline and pyridine, are common fragments of a vast majority of marketed drugs, which play central roles in modern drug design [20]. The introduced nitrogen atom may form a hydrogen bond with specific residues of the target receptor or receptor-bound water molecules that need to be satisfied [21]. Recently, some anti-tubulin agents were developed by replacing the 
3,4,5-trimethoxyphenyl ring of isoCA-4 with a quinazoline nucleus, which showed potent anti-proliferative activities against a range of human cancer cells, such as compound 4 (Figure 1B) [22]. Further docking study indicated that the $\mathrm{N}-1$ atom of such quinazolines interacted with $\beta$ Cys 241 of tubulin whereas the position of the $\mathrm{N}-3$ atom of these compounds was inadequate to interact with tubulin. Accordingly, Alami's group reported an isoCA-4 analog 5 with a quinoline moiety that displayed a nano- and sub-nanomolar level of cytotoxicity against five cancer cell lines [23]. Our group has focused on discovering and developing novel anticancer agents targeting tubulin-microtubule system and some $\mathrm{N}$-containing candidates were found in recent years, such as quinoline-chalcone derivative (6) [8] and quinoline-indole derivative (7) [24]. Compounds $\mathbf{6}$ and 7 were synthesized via replacing typical 3,4,5-trimethoxyphenyl (A ring) of CA-4 with quinoline rings, which all exhibited potent anticancer activity both in vitro and in vivo. Very recently, the heterocyclic ring pyridine nucleus was firstly introduced to replace the typical 3,4,5-trimethoxyphenyl to afford a series of novel pyridine-chalcone derivatives by our group. Among those pyridine-chalcone derivatives, compound $\mathbf{8}$ effectively suppressed the tumor volume and reduced tumor weight by $65.8 \%$. Further molecular modelling study revealed that the $N-1$ of pyridine moiety of $\mathbf{8}$ formed a critical hydrogen bond with residue Cys 241 [25]. Those results indicated that the substituted pyridine ring might be a good surrogate for the 3,4,5-trimethoxyphenyl ring of isoCA-4.

A.

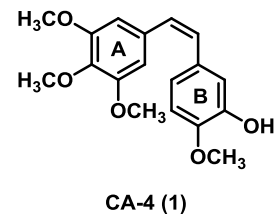

B.
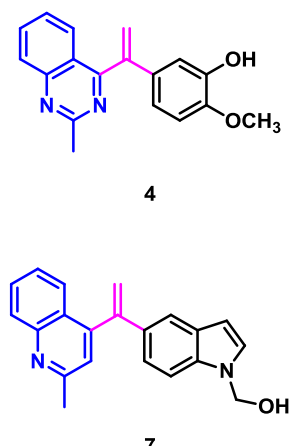
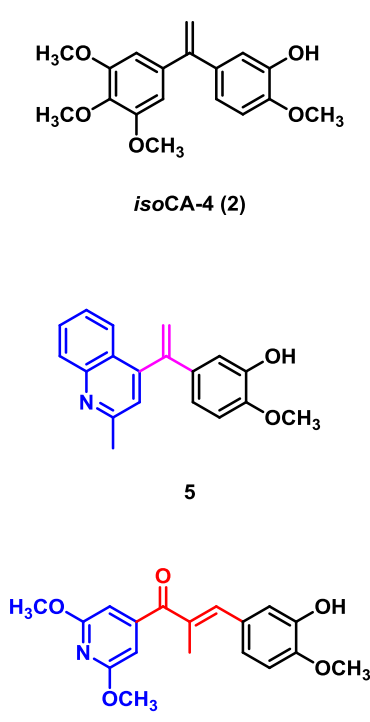
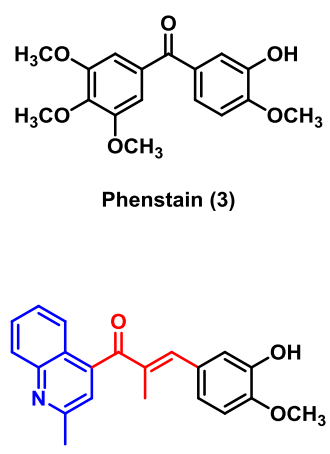

6 
Figure 1. (A) Representative anti-tubulin compounds; (B) Tubulin inhibitors bearing quinoline, quinazoline and pyridine moieties.

Based on these inspiring results, in this study, compounds isoCA-4 and $\mathbf{8}$ were used as novel lead compounds, the systematic exploration of the structure-activity relationships (SARs) of these two compounds were conducted. Thus, a series of novel isocombretapyridines were designed by replacing the 3,4,5-trimethoxyphenyl moiety of compound $\mathbf{2}$ with substituted pyridine rings as ring A, and introduced ring B with different substituents (Figure 2). Herein, we would like to report their synthesis and potent antitumor activities against human cancer cell lines. In addition, the potent tumor growth inhibition activity in $\mathrm{H} 22$ allograft mouse model and the fundamental cytotoxic mechanisms of representative compound 20a were also elucidated.

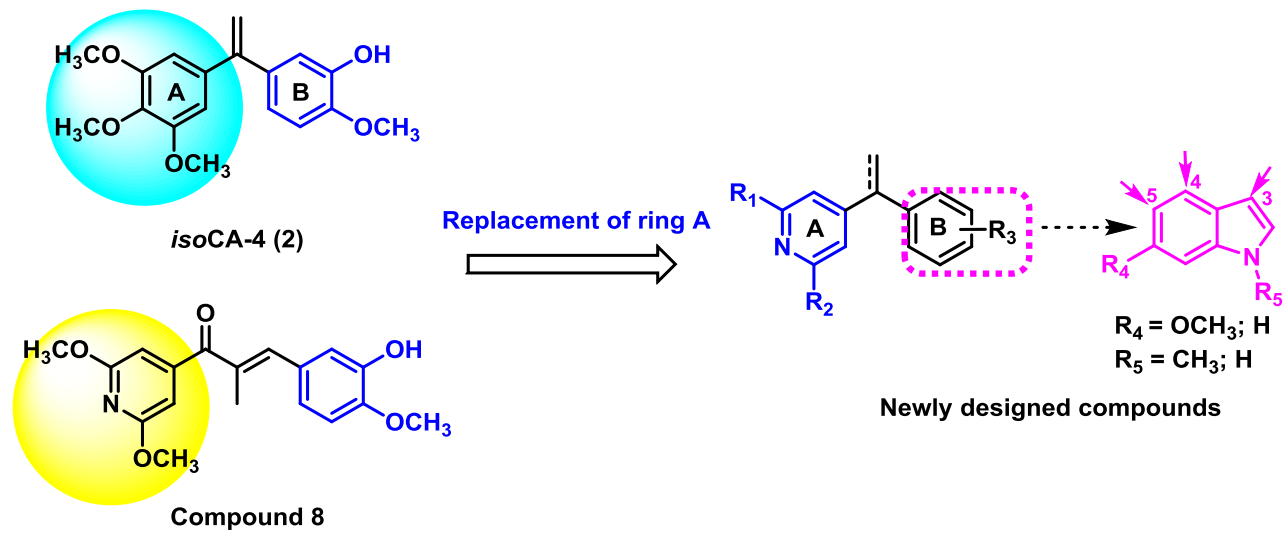

Figure 2. Design strategy of novel isocombretapyridines.

\section{Results and discussion}

\subsection{Chemistry}

Target compounds 15a-d, 16a-d and 17a-f bearing 2,6-dimethoxypyridine were synthesized through the palladium-catalyzed cross-coupling reactions between $N$-tosylhydrazones and various aryl halides, which was developed by Alami's group [26]. As outlined in Scheme 1, the starting material 2,6-dichloroisonicotinic acid was first reacted with $N$-methoxymethanamine to afford intermediate 9 which then underwent nucleophilic attack by methylmagnesium bromide $\left(\mathrm{CH}_{3} \mathrm{MgBr}\right)$ to give acetylpyridine 10. Then, acetylpyridine $\mathbf{1 0}$ was protected by using 2-bromoethanol in the presence of 1,8-diazabicyclo[5.4.0]undec-7-ene (DBU) to give acetal 11 which was further substituted with sodium methoxide to give intermediate 12. The 
intermediate 12 was deprotected by concentrated hydrochloric acid to afford $\mathbf{1 3}$ which was transformed into $N$-tosylhydrazone 14. Subsequently, $N$-tosylhydrazone 14 was coupled with various aryl bromides to afford corresponding target compounds (15a-d) in moderate yields, and the tert-butyldimethylsilyl (TBS) and benzenesulfonyl protecting groups were removed by corresponding deprotection methods. In addition, 16a-d were methylated or hydroxymethylated to give the corresponding target compounds 17a-e. Compound $\mathbf{1 5 d}$ was further reduced in the presence of $\mathrm{Pd} / \mathrm{C}$ under $\mathrm{H}_{2}$ atmosphere to give target compound $\mathbf{1 7 f}$ as a racemic mixture.<smiles>O=C(O)c1cc(Cl)nc(Cl)c1</smiles><smiles>CC(C)(C)C(=O)c1cc(Cl)nc(Cl)c1</smiles><smiles>CC1(c2cc(Cl)nc(Cl)c2)OCCO1</smiles><smiles>COc1cc(C2(C)OCCO2)cc(OC)n1</smiles>

9

10<smiles>[R]c1cc(C(=C)c2cc(OC)nc(OC)c2)cc(OCC)c1[R]</smiles>

15a $R_{1}+R_{2}=1$,3-dioxolane, $R_{3}=H$ $15 b \mathrm{R}_{1}=\mathrm{R}_{2}=\mathrm{OCH}_{3}, \mathrm{R}_{3}=\mathrm{H}$ $15 c R_{1}=R_{2}=R_{3}=O C H_{3}$ 15d $R_{1}=O H, R_{2}=O C H_{3}, R_{3}=H$

13

14<smiles>[R4]c1cc2[nH]ccc2cc1C(=C)c1cc(OC)nc(OC)c1</smiles>

16a-d<smiles>C=C(c1cc(OC)nc(OC)c1)c1ccc2[nH]ccc2c1</smiles>

16d<smiles>C=C(c1cc(OC)nc(OC)c1)c1ccc(OC)c(O)c1</smiles><smiles>CC</smiles><smiles>CCCC</smiles><smiles>[R4]c1cc2c(ccn2[R5])cc1C(=C)c1cc(OC)nc(OC)c1</smiles>

17a-d<smiles>C=C(c1cc(OC)nc(OC)c1)c1ccc2c(ccn2CO)c1</smiles>

17 e<smiles>COc1cc(C(C)c2ccc(OC)c(OC)c2)cc(OC)n1</smiles>

$17 f$
$16 \mathrm{a} \mathrm{R}_{4}=\mathrm{H}(\mathrm{C}-3)$

16b R $\mathrm{R}_{4}=\mathrm{OCH}_{3}(\mathrm{C}-3)$

16c $R_{4}=H(C-4)$

16d $R_{4}=H(C-5)$

17a $\mathrm{R}_{4}=\mathrm{H}, \mathrm{R}_{5}=\mathrm{CH}_{3}(\mathrm{C}-3)$

17b R $\mathrm{R}_{4}=\mathrm{OCH}_{3}, \mathrm{R}_{5}=\mathrm{CH}_{3}(\mathrm{C}-3)$

17c $\mathrm{R}_{4}=\mathrm{H}, \mathrm{R}_{5}=\mathrm{CH}_{3}(\mathrm{C}-4)$

17d $\mathrm{R}_{4}=\mathrm{H}, \mathrm{R}_{5}=\mathrm{CH}_{3}(\mathrm{C}-5)$

Scheme 1. The synthetic routes for target compounds 15a-d, 16a-d and 17a-f. Reagents and 
conditions: (a) $\mathrm{N}, \mathrm{O}$-Dimethylhydroxylamine hydrochloride, $\mathrm{HOBt}, \mathrm{EDCI}, \mathrm{Et}_{3} \mathrm{~N}, \mathrm{DCM}, 30^{\circ} \mathrm{C}$, overnight, 85.45\%; (b) $\mathrm{CH}_{3} \mathrm{MgBr}$, THF, $\mathrm{N}_{2}, 0^{\circ} \mathrm{C}, 1 \mathrm{~h}, 88.33 \%$; (c) $\mathrm{BrCH}_{2} \mathrm{CH}_{2} \mathrm{OH}$, DBU, Tol, $80{ }^{\circ} \mathrm{C}$, overnight, 72.81\%; (d) $\mathrm{MeONa}, \mathrm{MeOH}, 100{ }^{\circ} \mathrm{C}$, sealed tube, overnight; (e) con. $\mathrm{HCl}, 80^{\circ} \mathrm{C}, 1 \mathrm{~h}$, 88.26\%; (f) p-toluenesulfonhydrazide, EtOH, $90{ }^{\circ} \mathrm{C}, 3 \mathrm{~h}, 88.26 \%$; (g) 1) aryl halides, $\mathrm{PdCl}_{2}\left(\mathrm{CH}_{3} \mathrm{CN}\right)_{2}$, Xphos, $t$-BuOLi, $90{ }^{\circ} \mathrm{C}, 2 \mathrm{~h}, 56.51 \%$ - 72.82\%; 2) TBS was removed under condition: TBAF, THF, $1 \mathrm{~h}$ or benzenesulfonyl was removed under condition: $10 \% \mathrm{NaOH}, \mathrm{MeOH}$, reflux, 2 h, 90.51\% - 92.38\%; (h) $\mathrm{CH}_{3} \mathrm{I}, \mathrm{NaH}$, THF, r.t, 2 h, 88.6\%; (i) $37 \% \mathrm{HCHO}$ aqueous, $2 \mathrm{M}$ $\mathrm{NaOH}$, EtOH, r.t, 1 h, 66.74\%; (j) Pd/C, $\mathrm{H}_{2}$, r.t, 30 min, $82.75 \%$.

As shown in Scheme 2, isocombretapyridines with different substitutions at C-2 and C-6 positions of pyridine were synthesized. The intermediates 18a-b were prepared by nucleophilic reactions of acetylpyridine $\mathbf{1 0}$ with methanamine or pyrrolidine, respectively. Intermediate $\mathbf{1 1}$ reacted with various secondary amines followed by deprotection to afford the corresponding intermediates 18c-e. Then, $N$-tosylhydrazones 19a-e and $\mathbf{2 2}$ were coupled with TBS-protected 5-bromo-2-methoxyphenol, followed by deprotection to give the target compounds 20a-e and 23.

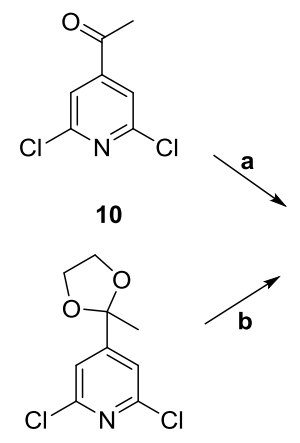

11

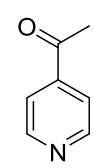

21

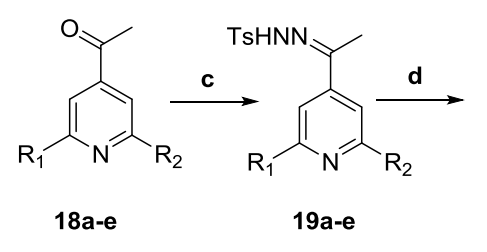


5-bromo-2-methoxyphenol, $\mathrm{PdCl}_{2}\left(\mathrm{CH}_{3} \mathrm{CN}\right)_{2}$, Xphos, $t$-BuOLi, $90{ }^{\circ} \mathrm{C}, 2 \mathrm{~h}, 23.57 \%$ - 69.13\%; 2 ) TBAF, THF, 1 h, 95.3\%.

The synthetic routes of target compounds $\mathbf{2 7} \mathbf{a}-\mathbf{b}$ and $32 \mathbf{a}-\mathbf{b}$ bearing methylpyridine moieties were depicted in Scheme 3. The important intermediate 29 was prepared by the reaction of indole-5-acid (28) with lithium methide $\left(\mathrm{CH}_{3} \mathrm{Li}\right)$, the $N-1$ of which was then methylated to afford intermediate 30. The intermediates $\mathbf{2 5}$ and $\mathbf{3 0}$ reacted with 4-methylbenzenesulfonhydrazide to give $N$-tosylhydrazones 26 and 31, which coupled with 4-chloro-2, 6-dimethylpyridine or 4-chloro-2-methylpyridine to obtain the corresponding target compounds $\mathbf{2 7} \mathbf{a}-\mathbf{b}$ and $\mathbf{3 2} \mathbf{a}-\mathbf{b}$.

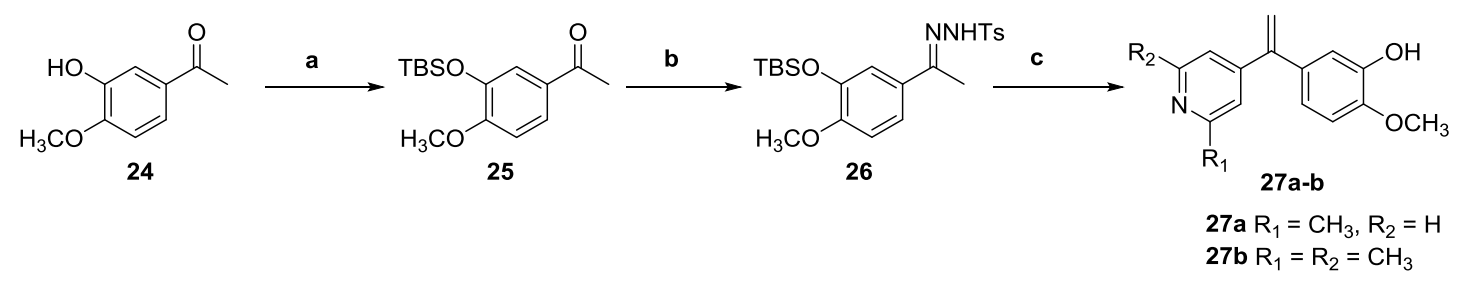

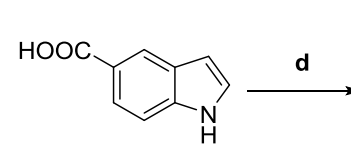

28

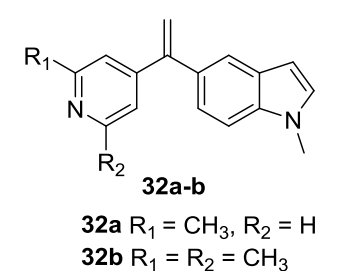

Scheme 3. The synthetic routes for target compounds 27a-b and 32a-b. Reagents and conditions:

(a) TBSCl, imidazole, DCM, r.t, 2 h, 95.5\%; (b) p-toluenesulfonhydrazide, EtOH, $90{ }^{\circ} \mathrm{C}, 3 \mathrm{~h}$, 85.7\%; (c) 1) 4-chloro-2-methylpyridine or 4-chloro-2,6-dimethylpyridine, $\mathrm{Pd}\left(\mathrm{CH}_{3} \mathrm{CN}\right)_{2} \mathrm{Cl}_{2}$, dppf, $\mathrm{Cs}_{2} \mathrm{CO}_{3}$, dioxane, $\mathrm{Ar}, 90{ }^{\circ} \mathrm{C}, 3 \mathrm{~h}, 19.70 \%$ - 25.72\% ; 2) TBAF, THF, r.t, 30 min, $92.5 \%$; (d) $\mathrm{CH}_{3} \mathrm{Li}$, THF, $0{ }^{\circ} \mathrm{C}, 1 \mathrm{~h}, 87.97 \%$; (e) $\mathrm{CH}_{3} \mathrm{I}, \mathrm{NaH}, \mathrm{THF}, 0{ }^{\circ} \mathrm{C}, 1 \mathrm{~h}, 89.71 \%$; (f) 4-chloro-2-methylpyridine or 4-chloro-2,6-dimethylpyridine, $\mathrm{PdCl}_{2}\left(\mathrm{CH}_{3} \mathrm{CN}\right)_{2}$, Xphos, $t$-BuOLi, $90{ }^{\circ} \mathrm{C}, 2 \mathrm{~h}, 62.76 \%$ - 67.59\%.

\subsection{In vitro cancer cell growth inhibition and the SARs.}

The anti-proliferative activities of the firstly prepared target compounds 15a-d, 16a-d and 17a-f with a 2,6-dimethoxypyridine moiety as the ring A were evaluated in human chronic myelogenous leukemia cells K562 using MTT assay, and isoCA-4 was 
used as a reference compound. As shown in Table 1, compound 15d featuring 3-hydroxyl-4-methoxylphenyl moieties displayed the most potent anti-proliferative activity with an $\mathrm{IC}_{50}$ value of $0.044 \mu \mathrm{M}$, which was about seven-fold more potent than the olefin-reduced racemic mixture of $\mathbf{1 7 f}\left(\mathrm{IC}_{50}=0.308 \mu \mathrm{M}\right)$. However, compounds 16a-d, of which olefin were substituted at different positions of indole ring, displayed lower activity $\left(\mathrm{IC}_{50}>1 \mu \mathrm{M}\right)$. Further, the anti-proliferative activities of substitutions at $N-1$ position of indole ring on activity were evaluated, compounds 17a-e containing methyl and hydroxymethyl group displayed similar activity compare to 16a-d except compound 17d with olefin substituted at C-5 position of indole rings, which exhibited moderate anti-proliferative activity $\left(\mathrm{IC}_{50}=0.181 \mu \mathrm{M}\right)$.

Furthermore, to investigate the importance of various substituents on the C-2 and C-6 of pyridine derivative 15d, compounds 20a-e, 23, 27a-b and 32a-b were synthesized by replacements of the methoxyl substituent. Compounds 20a, 20c, 27a-b and 32a-b all exhibited more potent anti-proliferative activity than 15d. Steric hindrance of the groups at the C-2 and C- 6 position of the pyridine moiety seemed to play an important role on the activity, as compounds with small steric groups displayed more potent anti-proliferative activity than those with large steric groups (20a $v s$ 20e). However, compound 23, with no substitution at C-2 and C-6 position of the pyridine nucleus, displayed a decreasing cytotoxicity against K562 cells when compared to $\mathbf{1 5 d}$, though the methoxy group has a larger steric hindrance.

Table 1. Anti-proliferative activities of all isocombretapyridines against K562 cell line ${ }^{a}$

\begin{tabular}{|c|c|c|c|}
\hline \multirow{2}{*}{ Compd. } & IC $_{50}$ values $(\mu \mathrm{M})^{b}$ & \multirow{2}{*}{ Compd. } & \multirow{2}{*}{$\frac{\text { IC }_{50} \text { values }(\mu \mathrm{M})}{\text { K562 }}$} \\
\hline & K562 & & \\
\hline $15 \mathbf{a}$ & $>1$ & $17 f$ & $0.308 \pm 0.031$ \\
\hline $15 b$ & $>1$ & 20a & $0.01 \pm 0.001$ \\
\hline $15 \mathrm{c}$ & $>1$ & $20 \mathrm{~b}$ & $>1$ \\
\hline 15d & $0.044 \pm 0.003$ & 20c & $0.016 \pm 0.022$ \\
\hline $16 \mathrm{a}$ & $>1$ & 20d & $>1$ \\
\hline $16 \mathrm{~b}$ & $>1$ & $20 \mathrm{e}$ & $>1$ \\
\hline
\end{tabular}




\begin{tabular}{cc||cc}
$\mathbf{1 6 c}$ & $>1$ & $\mathbf{2 3}$ & $0.151 \pm 0.012$ \\
$\mathbf{1 6 d}$ & $>1$ & $\mathbf{2 7 a}$ & $0.024 \pm 0.002$ \\
$\mathbf{1 7 a}$ & $>1$ & $\mathbf{2 7 b}$ & $0.012 \pm 0.001$ \\
$\mathbf{1 7 b}$ & $>1$ & $\mathbf{3 2 a}$ & $0.028 \pm 0.002$ \\
$\mathbf{1 7 c}$ & $>1$ & $\mathbf{3 2 b}$ & $0.021 \pm 0.001$ \\
$\mathbf{1 7 d}$ & $0.181 \pm 0.014$ & isoCA-4 & $0.006 \pm 0.001$ \\
$\mathbf{1 7}$ & $>1$ & & \\
\hline
\end{tabular}

${ }^{a} \mathrm{~K} 562$, human chronic myelogenous leukemia cells;

${ }^{b} \mathrm{IC}_{50}$ values are indicated as the mean $\pm \mathrm{SD}$ (standard deviation) of at least three independent experiments.

According to the results from K562 cell cytotoxicity assay, ten representative compounds were selected to test their anti-proliferative activities against three additional human cancer cell lines including human hepatocellular carcinoma (HepG2), human ileocecal cancer cells (HCT-8) and human breast cancer cells (MDA-MB-231), and one human normal lung fibroblast cell line (HFL-1). IsoCA-4 was utilized as the reference compound. The cytotoxic data in Table 2 indicated that the $\mathrm{IC}_{50}$ values of the representative compounds against three cancer cell lines were in nanomolar ranges and they also exhibited good selectivity against normal cell line HFL-1 cells. Moreover, the SARs were similar to their performances in K562 cell, which was the most sensitive cell line among four tested cell lines. Among them, compound 20a bearing 2-chloro-6-methyaminopyridine moiety exhibited the most excellent cytotoxicity activity with $\mathrm{IC}_{50}$ values ranging from 10 to $21 \mathrm{nM}$. The SARs of these novel isocombretapyridines were summarized in Figure 3.

Table 2. Cytotoxic activities of the selected compounds against three human cancer cell lines and one normal cell line ${ }^{a}$.

\begin{tabular}{ccccc}
\hline \multirow{4}{*}{ Compd. } & \multicolumn{4}{c}{$\mathrm{IC}_{50}$ values $(\mu \mathrm{M})^{b}$} \\
\cline { 2 - 5 } & HepG2 & HCT-8 & MDA-MB-231 & HFL-1 \\
\hline \multirow{2}{*}{$\mathbf{1 5 d}$} & $0.077 \pm 0.011$ & $0.086 \pm 0.012$ & $0.084 \pm 0.014$ & $0.792 \pm 0.054$
\end{tabular}




\begin{tabular}{ccccc}
$\mathbf{1 7 d}$ & $0.3 \pm 0.022$ & $0.288 \pm 0.019$ & $0.308 \pm 0.032$ & $0.879 \pm 0.062$ \\
$\mathbf{1 7 f}$ & $0.756 \pm 0.042$ & $0.794 \pm 0.045$ & $0.711 \pm 0.038$ & $1.104 \pm 0.103$ \\
$\mathbf{2 0 a}$ & $\mathbf{0 . 0 1 9} \pm \mathbf{0 . 0 0 2}$ & $\mathbf{0 . 0 2 1} \pm \mathbf{0 . 0 0 3}$ & $\mathbf{0 . 0 2} \pm \mathbf{0 . 0 0 1}$ & $\mathbf{0 . 1 1 8} \pm \mathbf{0 . 0 0 7}$ \\
$\mathbf{2 0 c}$ & $0.027 \pm 0.003$ & $0.029 \pm 0.003$ & $0.029 \pm 0.002$ & $0.114 \pm 0.006$ \\
$\mathbf{2 3}$ & $0.261 \pm 0.022$ & $0.222 \pm 0.019$ & $0.208 \pm 0.018$ & $0.696 \pm 0.048$ \\
$\mathbf{2 7 a}$ & $0.031 \pm 0.003$ & $0.032 \pm 0.004$ & $0.031 \pm 0.003$ & $0.189 \pm 0.018$ \\
$\mathbf{2 7 b}$ & $0.027 \pm 0.002$ & $0.031 \pm 0.003$ & $0.029 \pm 0.003$ & $0.086 \pm 0.012$ \\
$\mathbf{3 2 a}$ & $0.033 \pm 0.001$ & $0.032 \pm 0.002$ & $0.035 \pm 0.002$ & $0.201 \pm 0.025$ \\
$\mathbf{3 2 b}$ & $0.03 \pm 0.001$ & $0.031 \pm 0.002$ & $0.034 \pm 0.003$ & $0.176 \pm 0.018$ \\
isoCA-4 & $0.01 \pm 0.001$ & $0.01 \pm 0.001$ & $0.012 \pm 0.002$ & $0.086 \pm 0.010$ \\
\hline
\end{tabular}

${ }^{a}$ Cells were treated with different concentrations of the compounds for $72 \mathrm{~h}$. Cell viability was measured by the MTT assay as described in the Experimental Section.

${ }^{b} \mathrm{IC}_{50}$ values are indicated as the mean $\pm \mathrm{SD}$ (standard error) of at least three independent experiments.

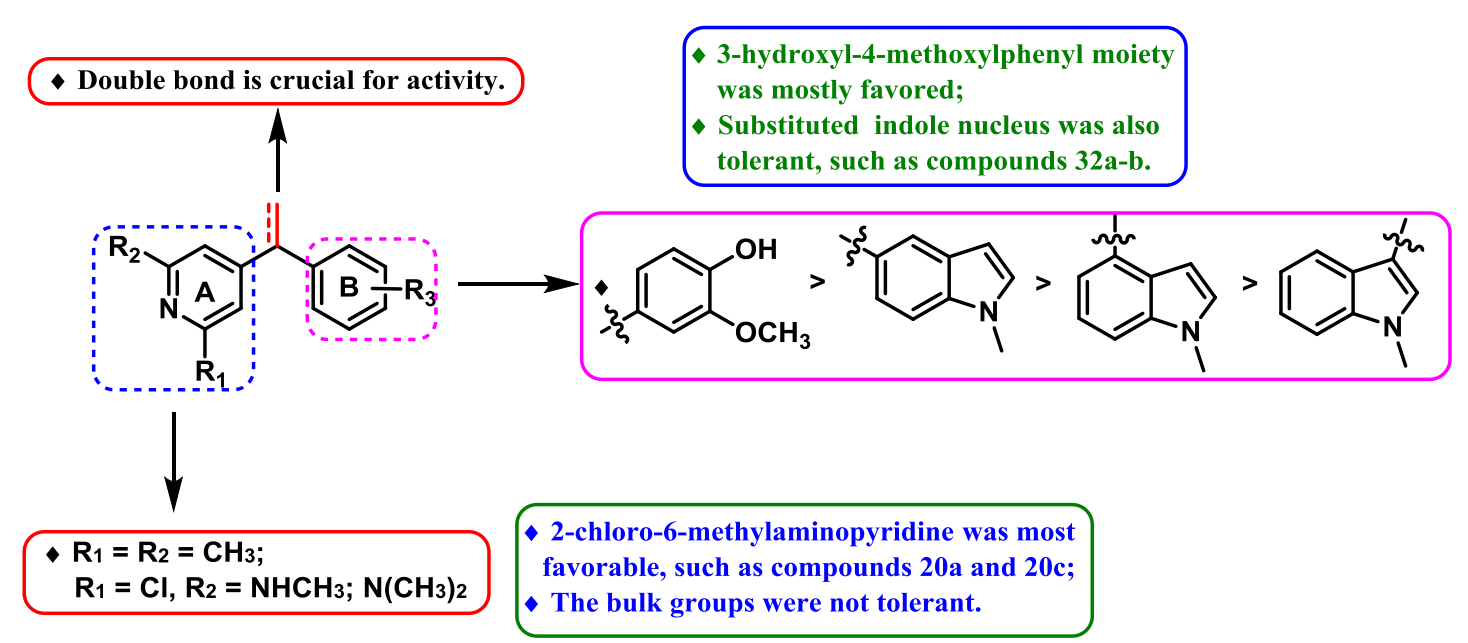

Figure 3. Summarized SARs of novel isocombretapyridines bearing different ring B.

\subsection{Analysis of tubulin polymerization in vitro}

To investigate whether the anti-proliferative activity of target compounds was caused by an interaction with tubulin system, the representative compound 20a was selected to evaluate the inhibitory effects on tubulin polymerization in vitro with isoCA-4 as the reference compound. The typical microtubule-destabilizing agent colchicine and microtubule-stabilizing agent taxol were employed as the positive 
control and negative control, respectively. As shown in Figure 4, taxol increased the absorbance obviously indicating that it enhanced tubulin polymerization, while 20a, isoCA-4 and colchicine decreased the absorbance, indicating that the tubulin polymerization was inhibited. Moreover, compound 20a $\left(\mathrm{IC}_{50}=3.15 \mu \mathrm{M}\right)$ exhibited only slightly less potent tubulin polymerization inhibitory activity than isoCA-4 (IC 50 $=2.37 \mu \mathrm{M})($ Table 3$)$. These results suggested that the mechanism of compound 20a was consistent with previously reported microtubule-destabilizing agents, certifying that compound 20a is a novel microtubule-destabilizing agent.

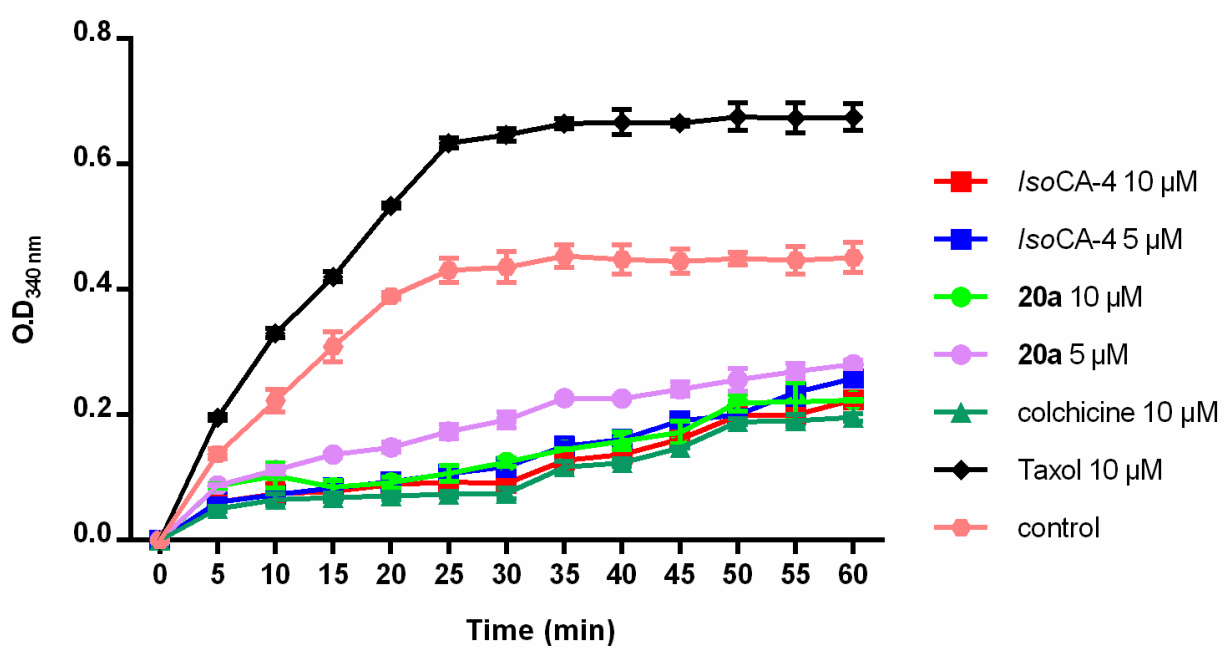

Figure 4. The compound 20a inhibited microtubule assembly in vitro. Purified tubulin protein at 2 $\mathrm{mg} / \mathrm{mL}$ in a reaction buffer incubated at $37{ }^{\circ} \mathrm{C}$ in the presence of $1 \%$ DMSO, test compounds (20a and isoCA-4 at 5 or $10 \mu \mathrm{M})$ or colchicine $(10 \mu \mathrm{M})$. Polymerizations were followed by an increase in fluorescence emission at $350 \mathrm{~nm}$ over a $60 \mathrm{~min}$ period at $37{ }^{\circ} \mathrm{C}$. The experiments were performed three times.

Compound 20a was also evaluated for potential inhibition of the binding of $\left[{ }^{3} \mathrm{H}\right]$ colchicine to tubulin. As shown in Table 3, 20a inhibited the binding of $\left[{ }^{3} \mathrm{H}\right]$ colchicine with the inhibition rates of $66.45 \%$ and $79.30 \%$ at 1 and $5 \mu \mathrm{M}$, respectively, somewhat less potent than isoCA-4 (74.04\% and 84.56\%). Therefore, due to its excellent activities both in the in vitro anti-proliferative assay and tubulin polymerization inhibition assay, 20a was selected for further mechanism studies.

Table 3. Inhibition of tubulin polymerization ${ }^{a}$ and colchicine binding to tubulin ${ }^{b}$

Compd. Inhibition of tubulin polymerization
Inhibition of colchicine binding

(\%) inhibition $\pm \mathrm{SD}$ 


\begin{tabular}{cc|cc}
\cline { 3 - 3 } & $\mathrm{IC}_{50}(\mu \mathrm{M})$ & $1 \mu \mathrm{M}$ & $5 \mu \mathrm{M}$ \\
\hline 20a & $3.15 \pm 0.26$ & $66.45 \pm 2.73$ & $79.30 \pm 1.66$ \\
isoCA-4 & $2.37 \pm 0.21$ & $74.04 \pm 2.52$ & $84.56 \pm 3.09$ \\
\hline
\end{tabular}

${ }^{a}$ The tubulin assembly assay measured the extent of assembly of $2 \mathrm{mg} / \mathrm{mL}$ tubulin after $60 \mathrm{~min}$ at

$37{ }^{\circ} \mathrm{C}$. Data are presented as mean from three independent experiments.

${ }^{b}$ Tubulin, $1 \mu \mathrm{M} ;\left[{ }^{3} \mathrm{H}\right]$-colchicine, $5 \mu \mathrm{M}$; and inhibitors, 1 or $5 \mu \mathrm{M}$.

\subsection{Molecular docking.}

The binding mode of compound 20a at the colchicine binding site of tubulin was performed using the Ligand Docking program in the Schrödinger software. As shown in Figure 5A, the superimposition of the best poses of docked compound 20a with CA-4 in the tubulin clearly demonstrated that compounds 20a and CA-4 adopt a similar binding mode in the colchicine binding pocket, with the 2-chloro-6-methyaminopyridine moiety deeply buried into the hydrophobic pocket shaped by residues $\beta$ Val238, $\beta$ Cys241, $\beta$ Leu242, $\beta$ Leu248, $\beta$ Ala250, $\beta$ Leu255, $\beta$ Ala316, $\beta$ Ile318 and $\beta$ Ile378. The docking pose for compound 20a showed a docking score of $-8.850 \mathrm{kcal} / \mathrm{mol}$, which was similar to the score obtained for the crystallized CA-4 (-8.595 kcal/mol). And one hydrogen bond was formed between 3'-OH of 20a and CA-4 and the main-chain amide of $\alpha$ Thr179. The $N$ atom of pyridine ring formed a pivotal hydrogen bond with residue $\beta$ Cys 241 , which was resembled with that of the 4-methoxy group of isoCA-4 (Figure 5B). Meanwhile, the methylamino group of pyridine ring formed an additional hydrogen bond interaction with residue $\beta$ Val238. In conclusion, the docking studies further suggested that 20a bound to the colchicine binding site on tubulin. 


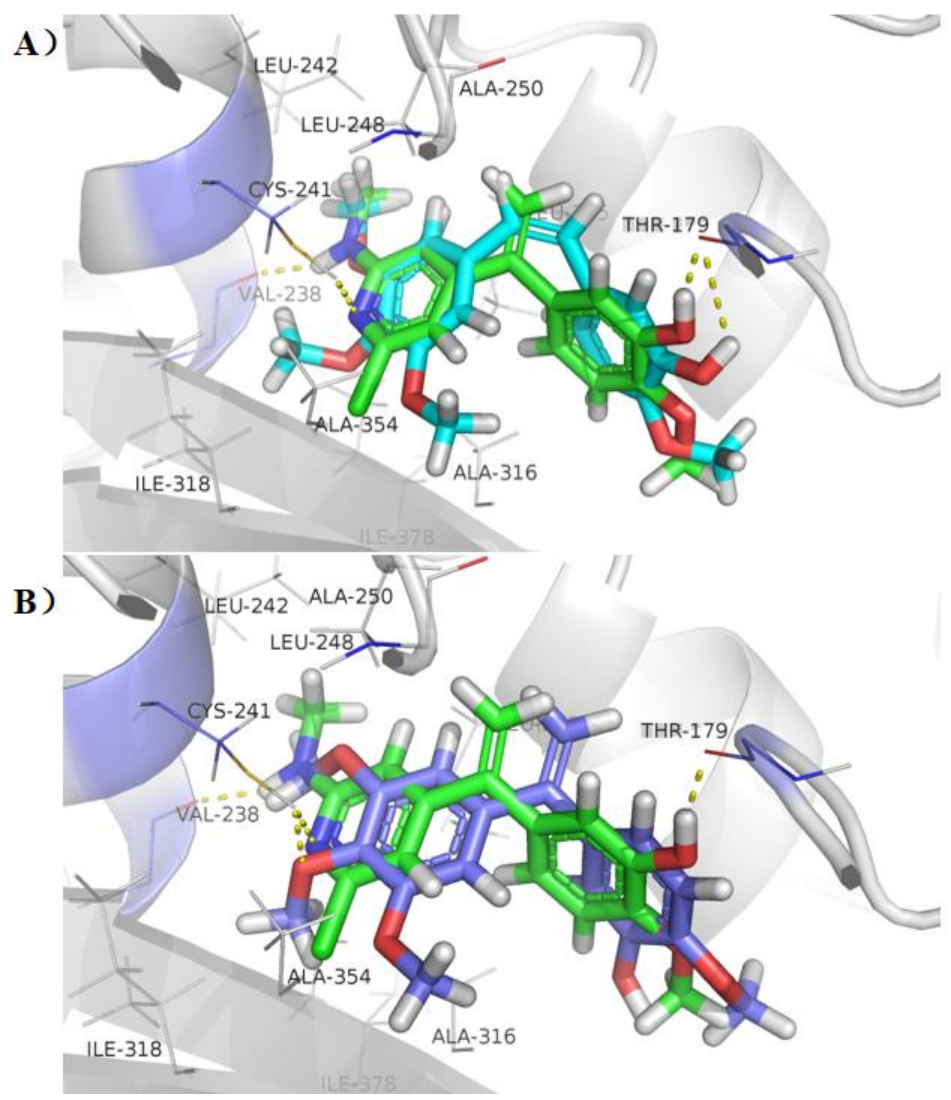

Figure 5. Proposed binding model of 20a (green) with tubulin (PDB code: 5LYJ), (A) Overlapping with CA-4 (cyan); (B) Overlapping with isoCA-4 (violet). The hydrogen bonds were shown in yellow dashed lines.

\subsection{Effects on cell cycle distribution and apoptosis assay}

It has been reported that the $\mathrm{G} 2 / \mathrm{M}$ phase cell-cycle arrest is a hallmark of tubulin-polymerizing inhibitors [27]. Thus, the cellular mechanisms of the representative compound 20a were further investigated using propidiumiodide (PI) staining by flow cytometry analysis in K562 cells, and isoCA-4 was used as the reference compound. K562 cells were treated with 20 a at $5 \mathrm{nM}, 10 \mathrm{nM}$ and $20 \mathrm{nM}$ (0.5-fold, 1-fold and 2-fold $\left.\mathrm{IC}_{50}\right)$ in parallel with isoCA-4 at $3 \mathrm{nM}, 6 \mathrm{nM}$ and $12 \mathrm{nM}$. As shown in Figure 6C and D, when treated with isoCA-4 at indicated concentration, the population of cells in $\mathrm{G} 2 / \mathrm{M}$ increased from $7.83 \%$ to $18.44 \%$ at high concentration compared with vehicle control. Simultaneously, compared to the vehicle control (7.70\%), 9.40\%, $11.54 \%$ and $15.28 \%$ of cells were arrested at G2/M phase in the presence of compound 20a at 5, 10 and $20 \mathrm{nM}$, respectively, which were similar to isoCA-4 (Figure 6A and B). Those results revealed that K562 cells treated 
with compound 20a were arrested at $\mathrm{G} 2 / \mathrm{M}$ phase in a concentration-dependent manner.

A.

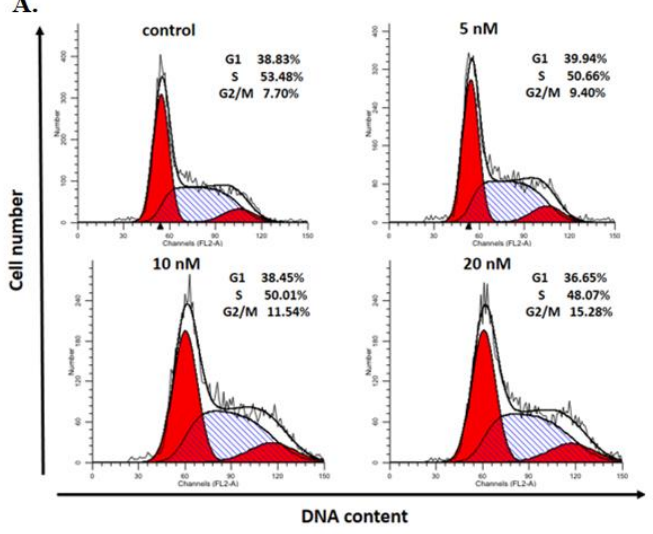

C.

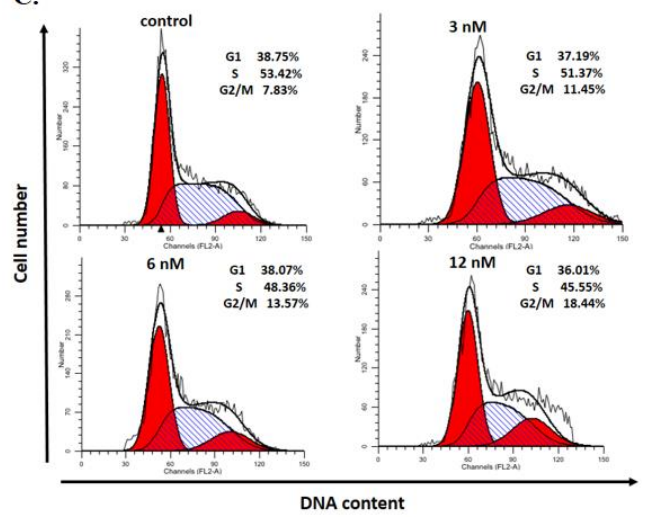

B.

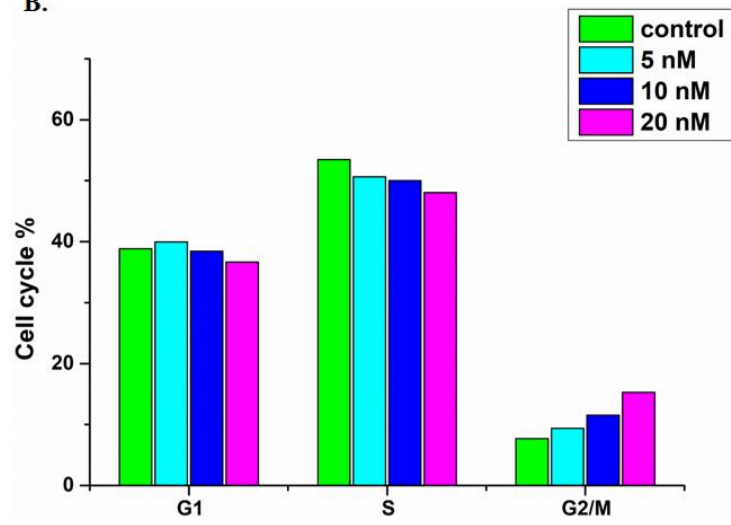

D.

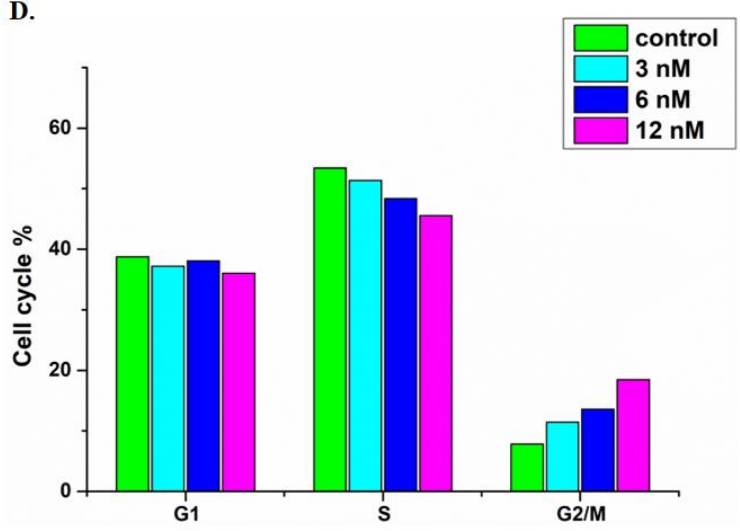

Figure 6. Compound 20a induced K562 cells cycle arrest at G2/M phase. A) K562 cells were treated with varying concentrations of $\mathbf{2 0 a}(0,5,10$, and $20 \mathrm{nM})$ for $48 \mathrm{~h}$, harvested and stained with PI to measure cell cycle profile by flow cytometry. The percentages of cells at different phases of cell cycle were analyzed by ModFit 4.1; B) Histograms display the percentage of cell cycle distribution after treatment with 20a; C) Cell cycle distribution of K562 cells cell lines after treatment with isoCA-4 at different concentration $(0,3,6$, and $12 \mathrm{nM})$; D) Histograms display the percentage of cell cycle distribution after treatment with isoCA-4.

Mitotic arrest of tumor cells by tubulin-targeting inhibitors is generally associated with cellular apoptosis [28]. To investigate the ability of compound 20a to induce apoptosis, an Annexin V-FITC/PI (AV/PI) dual staining assay was performed on K562 cells by flow cytometry [29]. The results were illustrated in Figure 7. Compared to the percentage of apoptosis cells in control group (3.25\%), the total percentage of the early (Annexin- $\mathrm{V}^{+} / \mathrm{PI}^{-}$) and late $\left(\right.$Annexin $-\mathrm{V}^{+} / \mathrm{PI}^{+}$) apoptosis cells were $10.46 \%$, 
$48.55 \%$ and $62.26 \%$ after being treated with $20 \mathrm{a}$ at 5,10 , and $20 \mathrm{nM}$ for $48 \mathrm{~h}$, respectively. It determined that compound 20a significantly induces cell apoptosis in K562 cells in a concentration-dependent manner.

A)

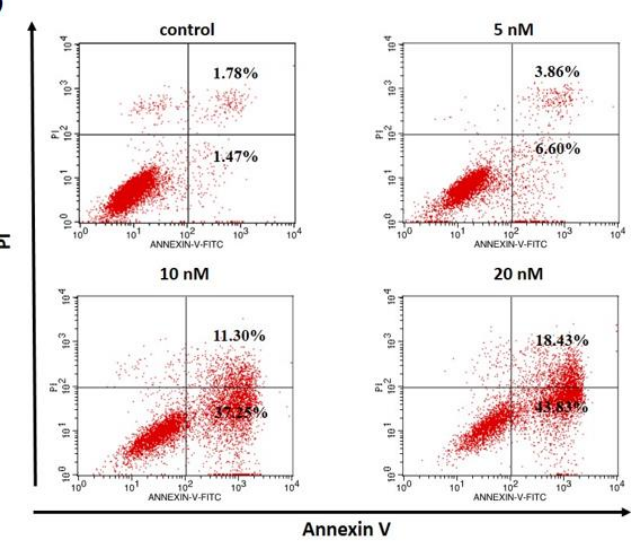

B )

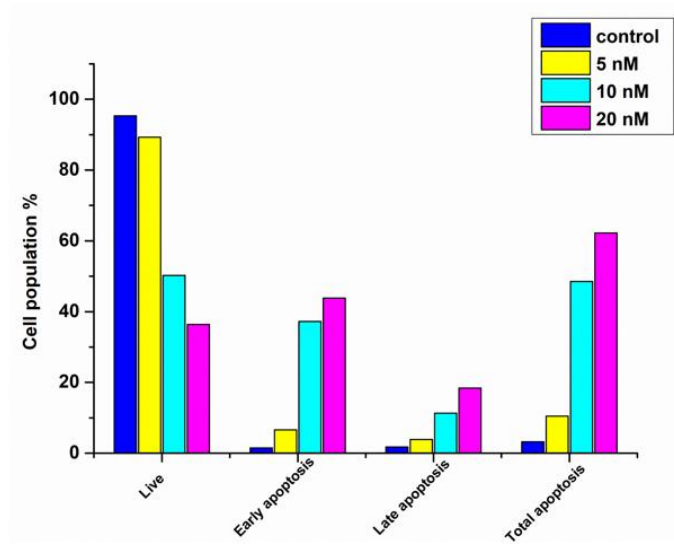

Figure 7. Compound 20a induced K562 cell apoptosis. A) K562 cells were incubated with varying concentrations of $20 \mathbf{a}(0,5,10$, and $20 \mathrm{nM})$ for $48 \mathrm{~h}$, and then harvested and stained with Annexin V/PI, followed by flow cytometric analysis. The percentages of cells in each stage of cell apoptosis were quantified by flow cytometry: (upper left quadrant) necrosis cells; (upper right quadrant) late-apoptotic cells; (bottom left quadrant) live cells; and (bottom right quadrant) early apoptotic cells. (B) Histograms display the percentage of cell distribution after treatment with 20a.

\subsection{Mitochondrial membrane potential analysis.}

The decrease of mitochondrial membrane potential (MMP) has been considered as an early event in apoptotic cells, and many antimitotic derivatives induce apoptosis through the mitochondrial pathway [30]. To confirm whether compound 20a could decrease the MMP of cancer cells, mitochondrial membrane potential assay by JC-1 staining of mitochondria in K562 was performed [31]. As shown in Figure 8, after exposure of K562 cells to various concentrations of compound 20a $(0,5,10$ and 20 $\mathrm{nM}$ ), the percentage of cells with collapsed MMP increased from 1.57\% to $38.34 \%$, indicated that compound 20a induces MMP collapse and mitochondrial dysfunction, which eventually triggered apoptotic cell death. 
A)

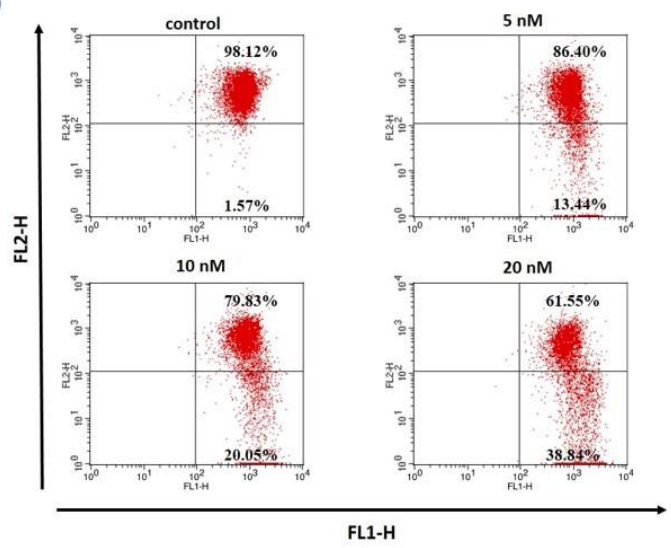

B )

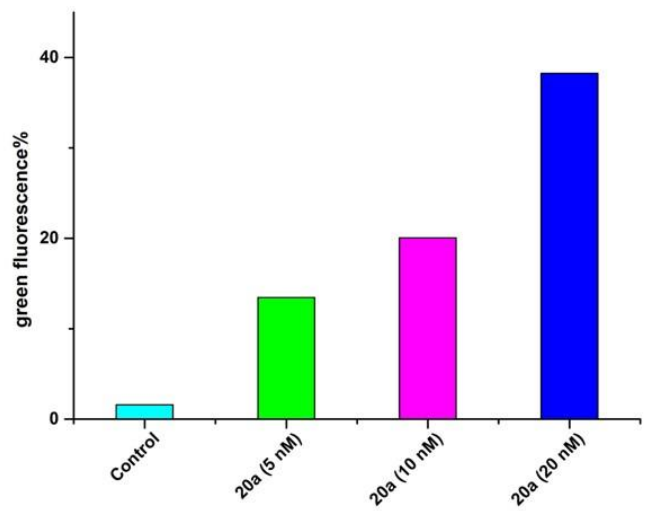

Figure 8. Assessment of mitochondrial membrane potential after treatment of K562 cells with 20a.

A) The K562 cells were treated with $\mathbf{2 0 a}$ at 5, 10, and $20 \mathrm{nM}$ or DMSO (1\%) for $48 \mathrm{~h}$, then incubated with the fluorescent probe JC-1 for $30 \mathrm{~min}$. The number of cells with collapsed mitochondrial membrane potentials was analyzed by flow cytometry. (B) Histograms display the percentage of green fluorescence.

\subsection{Anti-microtubule effects in K562 cells.}

To evaluate the effects of compound $\mathbf{2 0 a}$ on microtubule networks, immunofluorescent assay was performed on K562 cells. As shown in Figure 9, K562 cells in control group exhibited normal filamentous arrays. However, after treatment with increasing dosages of compound $\mathbf{2 0 a}(5,10$ and $20 \mathrm{nM})$ for $24 \mathrm{~h}$, the microtubule networks in cytoplasm were decreased and disrupted, which indicated that compound 20a could affect the cellular microtubule dynamics in a dose-dependent manner. 


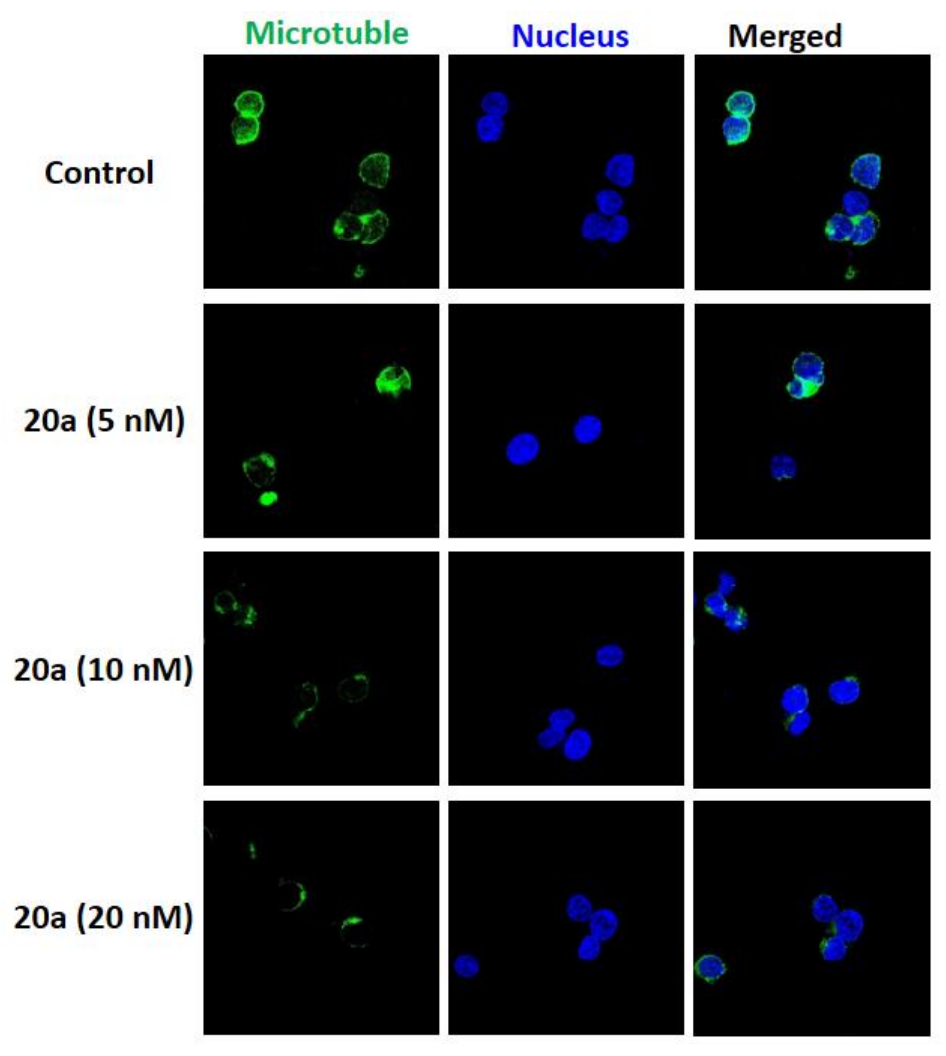

Figure 9. Immunofluorescence assay on microtubule network of K562 treated with 20a. K562 cells were treated with vehicle control $0.1 \%$ DMSO, 20a $(5,10$ and $20 \mathrm{nM})$. Then, the cells were fixed and stained with anti- $\alpha$-tubulin-FITC antibody (green), Alexa Fluor 488 dye and counterstained with DAPI (blue). The detection of the fixed and stained cells was performed with an LSM 570 laser confocal microscope (Carl Zeiss, Germany).

\subsection{Evaluation of anti-vascular activity in vitro.}

Angiogenesis, the development of the new blood vessels, plays a vital role in human cancer progression, development, and metastasis [32]. The agents binding to colchicine site can target tumor vasculature and prevent the formation of new blood vessels or disrupt existing microvessels [33]. Microtubules-targeting agents have also been reported to interfere with cell migration and motility at low concentrations. We evaluated the capacity of compound 20a to inhibit cell migration using a wound healing assay. As shown in Figure 10A and 10B, the control HUVECs that was not treated showed a wound closure of $76.3 \%$. However, after exposed to compound 20a at 5,10 , and $20 \mathrm{nM}$ for $24 \mathrm{~h}$, cells migrated into $67.6 \%, 55.3 \%$ and $49.2 \%$ of the wound area, respectively, suggesting that compound 20a significantly decreases 
wound closure in a concentration-dependent manner.

The HUVEC tube formation assay, a dynamic in vitro assay representing the key steps in angiogenesis $[34,35]$, was performed to assess the effect of compound 20a on inhibiting HUVECs capillary-like tubules formation. As shown in Figure 10C, after treatment with 5, 10 and $20 \mathrm{nM}$ of compound 20a, HUVEC tube formation was inhibited in a concentration-dependent manner. These results indicated that compound 20a has a significant effect on tubule-like disruption of HUVECs.

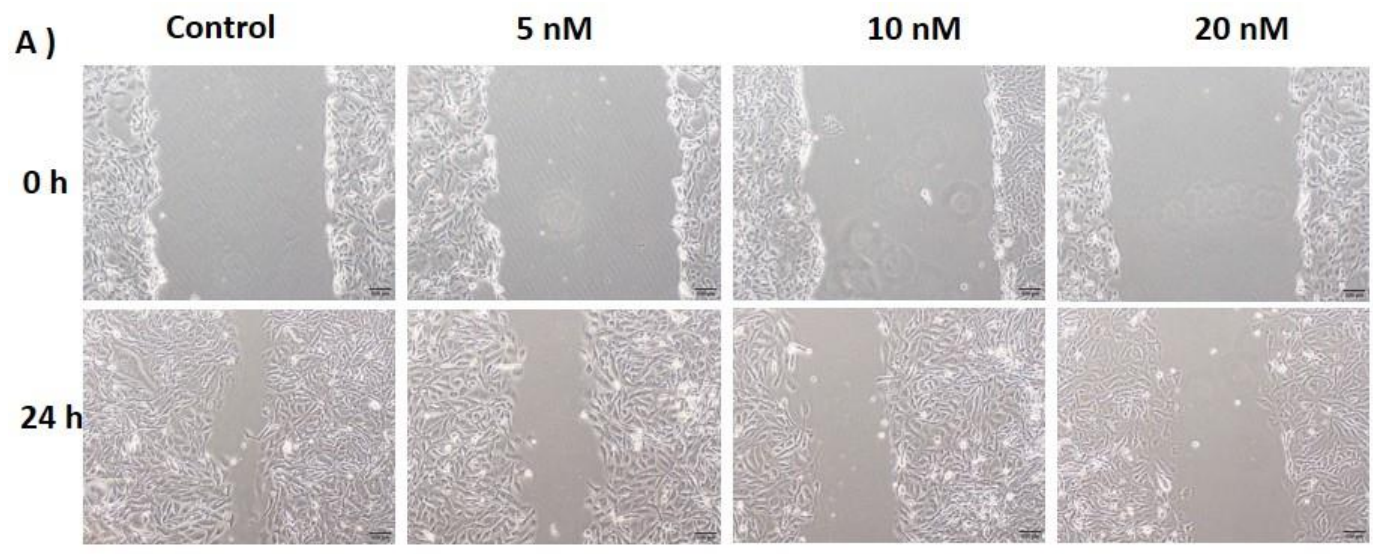

B )

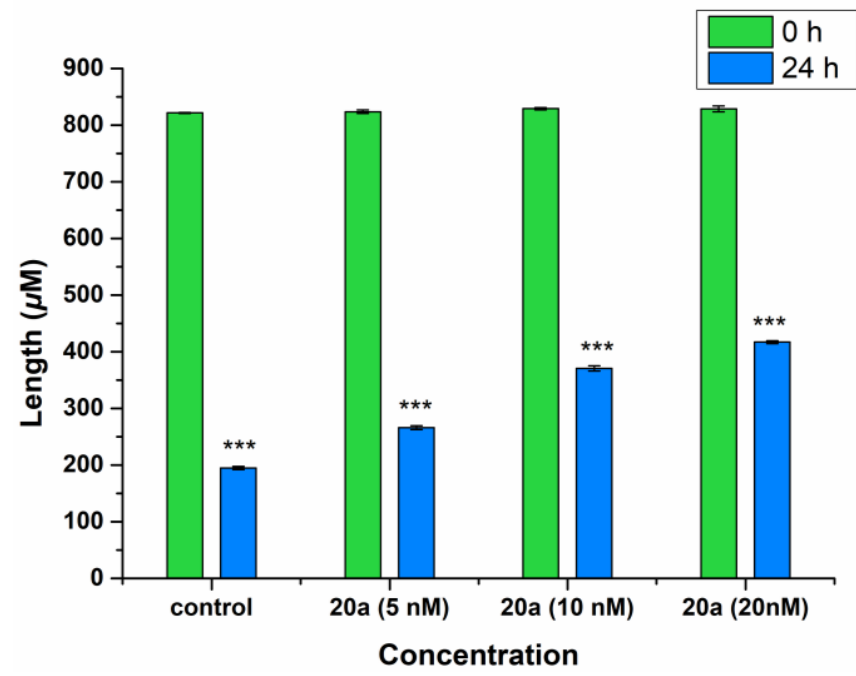

C)

Control

$5 \mathrm{nM}$

$10 \mathrm{nM}$

$20 \mathrm{nM}$
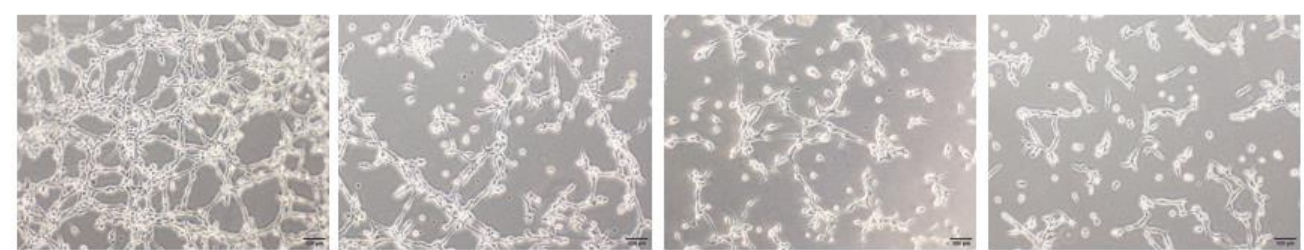

Figure 10. Effect of 20a on the HUVECs migration and tube formation. A) Scratches were created with sterile $200 \mu \mathrm{L}$ pipette and images were captured using phase contrast microscopy at $0 \mathrm{~h}$ and 
$24 \mathrm{~h}$ after treatments with 20a at different concentrations $(5,10$ and $20 \mathrm{nM})$ or $1 \%$ DMSO. B) Histograms display the length of the scratches at $0 \mathrm{~h}$ and $24 \mathrm{~h}$ after treatments with $0,5,10$ and 20 $\mathrm{nM}$ of 20a, $* * * \mathrm{P}<0.001 v s$ control group. C) Images depicting the formation of HUVEC capillary-like tubular network by treatments with $0,5,10$ and $20 \mathrm{nM}$ of $\mathbf{2 0 a}$ for $6 \mathrm{~h}$.

\subsection{Growth inhibition of mouse H22 allograft model in vivo.}

To investigate the in vivo antitumor potency of compound $\mathbf{2 0 a}$, the liver tumor allograft mouse model was established by subcutaneously injecting $\mathrm{H} 22$ cells at the logarithmic growth phase into the right flank of mice. IsoCA-4 and taxol was employed as the reference and positive control. In the initial MTT assay, the 20a, isoCA-4 and taxol displayed the potent anti-proliferative activity against $\mathrm{H} 22$ cells with the $\mathrm{IC}_{50}$ value of $0.017 \mu \mathrm{M}, 0.008 \mu \mathrm{M}$ and $0.084 \mu \mathrm{M}$, respectively. The doses for compounds 20a and isoCA-4 were selected 15 and $30 \mathrm{mg} / \mathrm{kg}$ as group. All results were represented in Figure 11, compound 20a displayed obvious and dose-dependent antitumor effect. The decrease in tumor weight reached $68.7 \%$ at doses of $30 \mathrm{mg} / \mathrm{kg}$ per day (i.v.) of 20a at 21 days after initiation of treatment as compared to vehicle, which is more potent than isoCA-4 (inhibition rate: $66.9 \%$ at a dose of $30 \mathrm{mg} / \mathrm{kg}$ ) and taxol ( $64.3 \%$, at a dose of $6 \mathrm{mg} / \mathrm{kg}$ ), respectively (Figure 11D). Importanly, in comparison with the control and vehicle groups, 20a did not cause an obvious loss of body weight even at the dose of $30 \mathrm{mg} / \mathrm{kg}$, which demonstrated that 20a displayed no significant toxicity in these mice (Figure 11C). To further evaluate the potential organ-related toxicities of $\mathbf{2 0 a}$, the $H \& E$ staining was conducted. As shown in Figure 12, the results of $H \& E$ staining of the heart, liver, spleen, lung and kidneys showed that treatment with $\mathbf{2 0 a}(30 \mathrm{mg} / \mathrm{kg})$ did not cause obvious toxicity in mice. All results indicated that compound 20a was efficacious and safe in inhibiting the growth of tumor in vivo and deserved further investigations for cancer therapy. 
A

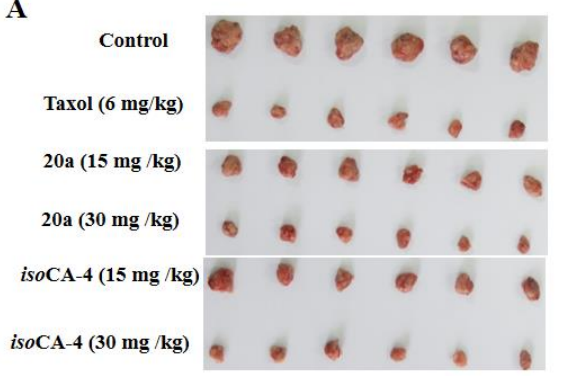

C

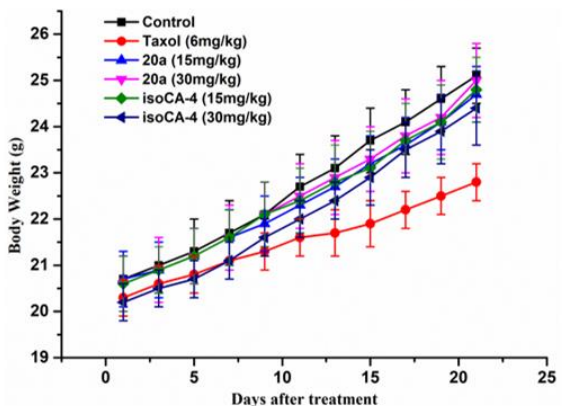

B

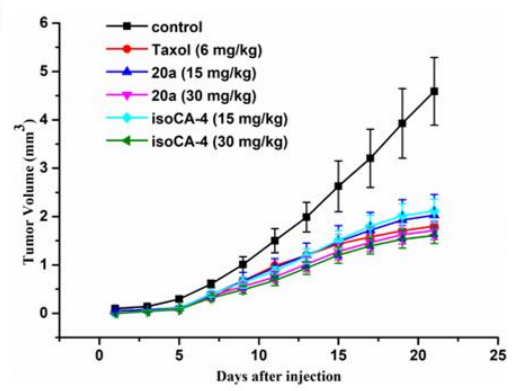

D

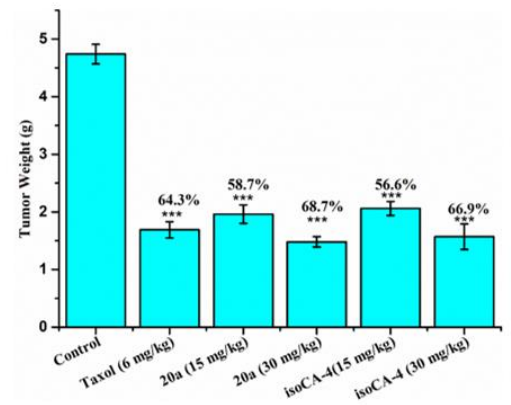

Figure 11. 20a inhibited liver tumor growth in vivo. After administered with vehicle, taxol (6 $\mathrm{mg} / \mathrm{kg}$ per 2 days), 20a (15 mg/kg per day), 20a (30 mg/kg per day), isoCA-4 (15 mg/kg per day), and isoCA-4 (30 mg/kg per day) for three weeks, the mice were sacrificed, and the tumors were weighted. (a) The images of tumors from mice at 21 days after initiation of treatment. (b) Tumor volume changes of mice during treatment. (c) Body weight changes of mice during treatment. (d) The weight of the excised tumors of each group. $* * * \mathrm{P}<0.001$ vs control group.

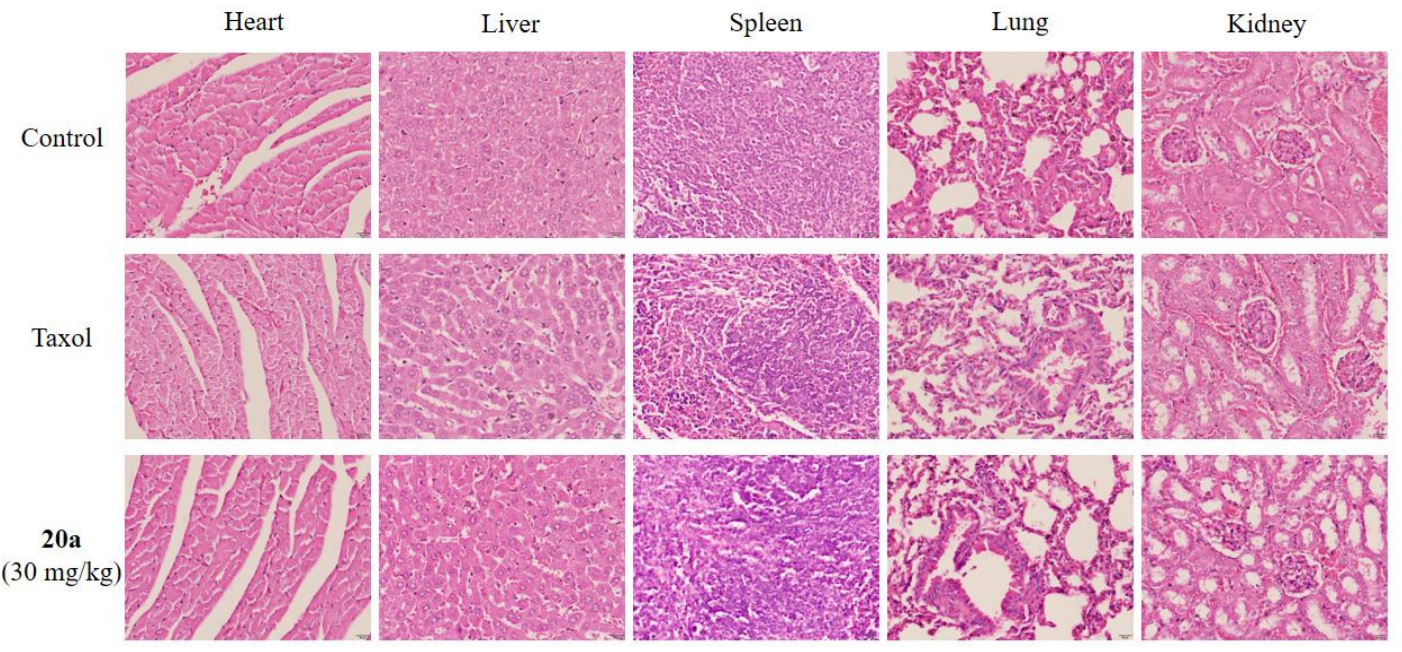

Figure 12. H\&E staining of heart, liver, spleen, lung, and kidney of 20a-treated mice. The organs (the heart, liver, spleen, lung and kidney) fixed by paraformaldehyde were processed for paraffin embedding and then stained with hematoxylin and eosin. The images shown are representatives from each group.

\section{Conclusion}


In conclusion, twenty-four novel isocombretapyridines were designed, synthesized and evaluated as tubulin polymerization inhibitors. Ten of the novel isocombretapyridines exhibited anti-proliferative activities against four cancer cell lines with $\mathrm{IC}_{50}$ values at nanomolar concentration ranges. Among them, compound 20a displayed the most potent anti-proliferative activity with $\mathrm{IC}_{50}$ values ranging from 0.01 to $0.021 \mu \mathrm{M}$. Moreover, 20a showed good tubulin polymerization inhibitory activity $\left(\mathrm{IC}_{50}=3.15 \mu \mathrm{M}\right)$, which was correlated with inhibition of $\left[{ }^{3} \mathrm{H}\right]$ colchicine binding to tubulin. Further cellular mechanistic studies indicated that 20a disrupted microtubule networks, arrested cell cycle at G2/M phase, induced apoptosis and depolarized mitochondria of K562 cells in a dose-dependent manner. Moreover, 20a displayed potent anti-vascular activity in both HUVECs wound healing and tube formation assays. Importantly, in a H22 liver cancer allograft mouse model, 20a could effectively suppressed the tumor volume and reduced tumor weight by $68.7 \%$ at the dose of $30 \mathrm{mg} / \mathrm{kg}$ per day (i.v.) without apparent toxicity. Collectively, these results highlighted that 20a may be a promising potent antitumor and anti-vascular candidate for the treatment of cancers, which deserves further investigation.

\section{Experimental section}

\subsection{Chemistry}

\subsubsection{General}

All commercially available starting materials and solvents were reagent grade and used without further purification unless otherwise noted. ${ }^{1} \mathrm{H}$ NMR and ${ }^{13} \mathrm{C} N M R$ spectra were recorded on Bruker-300 or Bruker-400 spectrometers using $\mathrm{CDCl}_{3}$ or DMSO- $d_{6}$ as solvent (TMS as internal standard). Data are reported as follows: chemical shift $(\delta)$ in ppm, multiplicity (s: singlet, d: doublet, t: triplet, q: quartet, brs: broad singlet, m: multiple), coupling constant $J(\mathrm{~Hz})$, and integration. High Resolution Mass measurement was performed on Agilent QTOF 6520 mass spectrometer with electron spray ionization (ESI) as the ion source. Flash column chromatography was carried out using commercially available silica gel (200 - 300 mesh) under pressure. The purity of the representative compounds is $\geq 95 \%$ as 
analyzed by the HPLC (Shimadzu LC-20AT) on an Aglient ZORBAX Eclipse Plus C18 $(4.6 \times 150 \mathrm{~mm}, 5 \mu \mathrm{m})$ using a mixture of solvent $0.1 \%$ trifluoroacetic acid/acetonitrile at the flow rate of $1.0 \mathrm{~mL} / \mathrm{min}$ and peak detection at $254 \mathrm{~nm}$ under UV

\subsubsection{The synthesis of intermediate 9.}

2,6-Dichloroisonicotinic acid $(10 \mathrm{~g}, 54.6 \mathrm{mmol}), \mathrm{N}, O$-dimethylhydroxylamine hydrochloride (7.99 g, $81.89 \mathrm{mmol})$, HOBt (8.85 g, 65,52 mmol) and EDCI (12.56 g, $65.52 \mathrm{mmol})$ were dissolved in DCM and $\mathrm{Et}_{3} \mathrm{~N}(11.38 \mathrm{~mL}, 81.89 \mathrm{mmol})$ was added. After being stirred at room temperature overnight, the reaction mixture was filtered and the solvent was evaporated in vacuo. The crude product was purified by column chromatography with petroleum / ethyl acetate (4:1) to give intermediate $\mathbf{9}$ as a white solid (9.97 g, 85.45\%); ${ }^{1} \mathrm{H}$ NMR (300 MHz, $\left.\mathrm{CDCl}_{3}\right) \delta 7.50$ (s, 2H), 3.58 (s, 3H), 3.37 $(\mathrm{s}, 3 \mathrm{H})$.

\subsubsection{The synthesis of intermediate 10.}

The intermediate 9 (9.97 $\mathrm{g}, 42.41 \mathrm{mmol})$ were dissolved in anhydrous THF and methylmagnesium bromide in THF (3 M, $14.14 \mathrm{~mL}, 42.41 \mathrm{mmol})$ was added slowly under $\mathrm{N}_{2}$ atmosphere at $0{ }^{\circ} \mathrm{C}$ After stirring for $1 \mathrm{~h}$, the reaction was quenched by $\mathrm{NH}_{4} \mathrm{Cl}$ aqueous, and extracted with $\mathrm{CH}_{2} \mathrm{Cl}_{2}(3 \times 150 \mathrm{~mL})$. The combined organic layers were then washed with brine, dried over anhydrous $\mathrm{Na}_{2} \mathrm{SO}_{4}$, and concentrated under a vacuum to obtain $\mathbf{1 0}(7.12 \mathrm{~g}, 88.33 \%)$ as yellow liquid, the crude product was used without purification; ${ }^{1} \mathrm{H}$ NMR $\left(300 \mathrm{MHz}, \mathrm{CDCl}_{3}\right) \delta 7.69(\mathrm{~s}, 2 \mathrm{H}), 2.64(\mathrm{~s}, 3 \mathrm{H})$.

\subsubsection{The synthesis of intermediate 11.}

The intermediate 10 (7.12 g, $37.47 \mathrm{mmol})$ and 2-bromoethanol (13.27 mL, 187.35 mmol) were dissolved in toluene and DBU (16.81 $\mathrm{mL}, 112.41 \mathrm{mmol})$ was added dropwise, then the mixture was stirred at $90{ }^{\circ} \mathrm{C}$. After stirring overnight, toluene was removed under a vacuum to obtain crude product which was purified by column chromatography with petroleum / ethyl acetate (30:1) to give intermediate $\mathbf{1 1}$ as a white solid (6.385 g, 72.81\%); ${ }^{1} \mathrm{H}$ NMR (300 MHz, $\left.\mathrm{CDCl}_{3}\right) \delta 7.73(\mathrm{~s}, 2 \mathrm{H}), 4.03(\mathrm{t}, J=$ $6.8 \mathrm{~Hz}, 2 \mathrm{H}), 3.67(\mathrm{t}, J=6.9 \mathrm{~Hz}, 2 \mathrm{H}), 1.76(\mathrm{~s}, 3 \mathrm{H})$. 


\subsubsection{The synthesis of intermediate 12 .}

To the solutions of 11 ( $4 \mathrm{~g}, 17.09 \mathrm{mmol})$ in $20 \mathrm{~mL} \mathrm{MeOH}$ at sealed tube, sodium methoxide (9.23 g, $170.88 \mathrm{mmol}$ ) was added. After stirring at $100{ }^{\circ} \mathrm{C}$ overnight, the mixtures were cooled to room temperature, and the solvent was removed in vacuo. After being extracted with EA $(3 \times 120 \mathrm{~mL})$, the combined organic layers were washed with brine, dried over anhydrous $\mathrm{Na}_{2} \mathrm{SO}_{4}$, and concentrated in vacuo to provide 3.48 g crude intermediate 12 as a yellow solid; ${ }^{1} \mathrm{H}$ NMR $\left(300 \mathrm{MHz}, \mathrm{CDCl}_{3}\right) \delta$ $6.03(\mathrm{~s}, 2 \mathrm{H}), 3.93(\mathrm{t}, J=6.7 \mathrm{~Hz}, 2 \mathrm{H}), 3.83(\mathrm{~s}, 6 \mathrm{H}), 3.64(\mathrm{t}, J=6.5 \mathrm{~Hz}, 2 \mathrm{H}), 1.68$ (s, $3 \mathrm{H})$.

\subsubsection{The synthesis of intermediate $\mathbf{1 3 .}$}

The $3.48 \mathrm{~g}$ crude intermediate $\mathbf{1 2}$ was added in $20 \mathrm{~mL}$ concentrated hydrochloric acid. After stirring for $1 \mathrm{~h}$ at $80{ }^{\circ} \mathrm{C}, 2 \mathrm{M} \mathrm{NaOH}$ was added to adjust the $\mathrm{pH}$ to 8 . The solution was extracted with EA $(3 \times 100 \mathrm{~mL})$, then the collected organic layers were washed with saturated brine, dried over anhydrous $\mathrm{Na}_{2} \mathrm{SO}_{4}$, and concentrated in vacuo to afford the crude product. The crude product was purified by column chromatography with petroleum / ethyl acetate (40:1) to give intermediate 13 (2.48 g, $88.26 \%$ ) as a light yellow solid; ${ }^{1} \mathrm{H}$ NMR $\left(300 \mathrm{MHz}, \mathrm{CDCl}_{3}\right) \delta 6.74$ (s, 2H), 3.95 (s, 6H), 2.55 (s, 3H), ${ }^{13} \mathrm{C}$ NMR (75 MHz, $\left.\mathrm{CDCl}_{3}\right) \delta 212.5,164.1,148.7,99.7,53.9,27.0$.

\subsubsection{The synthesis of intermediate 14 .}

The intermediate $\mathbf{1 3}(2.48 \mathrm{~g}, 13.69 \mathrm{mmol})$ was dissolved in EtOH and 4-methylbenzenesulfonohydrazide (3.06 g, $16.42 \mathrm{mmol})$ was added. After stirring for $3 \mathrm{~h}$ at $80^{\circ} \mathrm{C}$, the precipitates were collected by filtration, washed with cold EtOH and dried to afford intermediate $\mathbf{1 4}(3.95 \mathrm{~g}, 82.26 \%)$ as a light yellow solid.

\subsubsection{The synthesis of target compounds 15 a-d and 16a-d.}

To a solution of the key intermediate $14(75 \mathrm{mg}, 0.16 \mathrm{mmol})$ in $2 \mathrm{~mL}$ dioxane under $\mathrm{N}_{2}$ atmosphere, the various aryl bromides $(0.18 \mathrm{mmol})$, Xphos $(8 \mathrm{mg}, 0.016 \mathrm{mmol})$, $\mathrm{Pd}\left(\mathrm{CH}_{3} \mathrm{CN}\right)_{2} \mathrm{Cl}_{2}(4 \mathrm{mg}, 0.016 \mathrm{mmol})$ and $t$-BuOLi $(29 \mathrm{mg}, 0.36 \mathrm{mmol})$ were added. After stirring for $3 \mathrm{~h}$ at $90{ }^{\circ} \mathrm{C}$, the precipitates were removed by filtration. And the filtrates were concentrated under a vacuum to afford the crude products, which were 
purified by column chromatography with petroleum/ethyl acetate to give compounds 15a-c in moderate yields. To a solution of TBS-protected $\mathbf{1 5 d}(68 \mathrm{mg}, 0.17 \mathrm{mmol})$ in $5 \mathrm{~mL}$ THF, TBAF were added. After stirring for $30 \mathrm{~min}$, the solvent was removed to obtain crude product, which was purified by column chromatography with petroleum/ethyl acetate (6: 1) to give compounds $\mathbf{1 5 d}$ (45 $\mathrm{mg}, 92.50 \%)$. To a solution of benzenesulfonyl-protected 16a-d in $5 \mathrm{~mL} \mathrm{MeOH}, 10 \% \mathrm{NaOH}$ solution was added. After stirring for $2 \mathrm{~h}$ at refluxing temperature, $\mathrm{MeOH}$ was removed in vacuo. The mixture was extracted with EA $(3 \times 50 \mathrm{~mL})$, and the combined organic layers were then washed with brine, dried over anhydrous $\mathrm{Na}_{2} \mathrm{SO}_{4}$, and concentrated in vacuo to provide the crude product, which was purified by column chromatography with petroleum/ethyl acetate to give 16a-d in moderate yields.

4.1.8.1 4-(1-(Benzo[d][1,3]dioxol-5-yl)vinyl)-2,6-dimethoxypyridine (15a).

Yield 66.8\%, white solid; ${ }^{1} \mathrm{H}$ NMR $\left(300 \mathrm{MHz} \mathrm{CDCl}_{3}\right) \delta 6.81(\mathrm{~d}, J=1.7 \mathrm{~Hz}, 1 \mathrm{H})$, $6.81-6.77(\mathrm{~m}, 2 \mathrm{H}), 6.29(\mathrm{~s}, 2 \mathrm{H}), 5.99(\mathrm{~s}, 2 \mathrm{H}), 5.46(\mathrm{~d}, J=1.0 \mathrm{~Hz}, 2 \mathrm{H}), 3.94(\mathrm{~s}, 6 \mathrm{H})$; ${ }^{13} \mathrm{C}$ NMR $\left(101 \mathrm{MHz}, \mathrm{CDCl}_{3}\right) \delta 165.9,163.3,154.6,147.8,147.5,134.2,122.0,115.1$, 108.5, 108.1, 101.2, 100.8, 53.6; HR-MS (ESI) $m / z$ : calcd for $\mathrm{C}_{16} \mathrm{H}_{16} \mathrm{NO}_{4}[\mathrm{M}+\mathrm{H}]^{+}$ 286.1074, found 286.1077.

\subsubsection{4-(1-(3,4-Dimethoxyphenyl)vinyl)-2,6-dimethoxypyridine (15b).}

Yield 60\%, yellow solid; ${ }^{1} \mathrm{H}$ NMR $\left(300 \mathrm{MHz}, \mathrm{CDCl}_{3}\right) \delta 6.87-6.84(\mathrm{~m}, 1 \mathrm{H}), 6.85-$ $6.78(\mathrm{~m}, 2 \mathrm{H}), 6.28(\mathrm{~d}, J=1.4 \mathrm{~Hz}, 2 \mathrm{H}), 5.46(\mathrm{~s}, 2 \mathrm{H}), 3.92(\mathrm{~s}, 6 \mathrm{H}), 3.90(\mathrm{~s}, 3 \mathrm{H}), 3.85$ (s, $3 \mathrm{H}) ;{ }^{13} \mathrm{C} \mathrm{NMR}\left(75 \mathrm{MHz}, \mathrm{CDCl}_{3}\right) \delta 163.3,154.7,149.1,148.7,147.9,132.9,120.9$, 114.9, 111.3, 110.9, 100.7, 55.9, 53.5; HR-MS (ESI) $m / z$ : calcd for $\mathrm{C}_{17} \mathrm{H}_{20} \mathrm{NO}_{4}$ $[\mathrm{M}+\mathrm{H}]^{+}$302.1387, found 302.1390.

\subsubsection{2, 6-Dimethoxy-4-(1-(3,4,5-trimethoxyphenyl)vinyl)pyridine (15c).}

Yield 65\%, yellow oil; ${ }^{1} \mathrm{H}$ NMR $\left(300 \mathrm{MHz}, \mathrm{CDCl}_{3}\right) \delta 6.51(\mathrm{~s}, 2 \mathrm{H}), 6.29(\mathrm{~s}, 2 \mathrm{H})$, $5.53(\mathrm{~s}, 1 \mathrm{H}), 5.48(\mathrm{~s}, 1 \mathrm{H}), 3.93(\mathrm{~s}, 6 \mathrm{H}), 3.87(\mathrm{~s}, 3 \mathrm{H}), 3.82(\mathrm{~s}, 6 \mathrm{H}) ;{ }^{13} \mathrm{C}$ NMR $(101$ $\left.\mathrm{MHz}, \mathrm{CDCl}_{3}\right) \delta 163.3,154.3,152.95,148.3,138.0,135.8,115.9,105.5,100.7,60.9$, 56.2, 53.6; HR-MS (ESI) $m / z$ : calcd for $\mathrm{C}_{18} \mathrm{H}_{22} \mathrm{NO}_{5}[\mathrm{M}+\mathrm{H}]^{+} 332.1492$, found 332.1497; Purity: 99.66\% (by HPLC).

4.1.8.4 5-(1-(2,6-Dimethoxypyridin-4-yl)vinyl)-2-methoxyphenol (15d). 
Yield 58.4\%, yellow solid; ${ }^{1} \mathrm{H}$ NMR $\left(300 \mathrm{MHz}, \mathrm{CDCl}_{3}\right) \delta 6.92(\mathrm{~s}, 1 \mathrm{H}), 6.79(\mathrm{~d}, J=$ $1.3 \mathrm{~Hz}, 2 \mathrm{H}), 6.27$ (s, 2H), 5.60 (s, 1H), 5.46 (s, 1H), 5.42 (s, 1H), 3.91 (s, 6H), 3.90 (s, $3 \mathrm{H}) ;{ }^{13} \mathrm{C}$ NMR $\left(75 \mathrm{MHz}, \mathrm{CDCl}_{3}\right) \delta 163.2,154.7,147.7,146.5,145.3,133.4,120.1$, 115.0, 114.3, 110.2, 100.8, 56.0, 53.6; HR-MS (ESI) $m / z$ : calcd for $\mathrm{C}_{16} \mathrm{H}_{18} \mathrm{NO}_{4}$ $[\mathrm{M}+\mathrm{H}]^{+}$288.1230, found 288.1230; Purity: 99.79\% (by HPLC).

\subsubsection{3-(1-(2,6-Dimethoxypyridin-4-yl)vinyl)-1H-indole (16a).}

Yield 67.7\%, yellow oil; ${ }^{1} \mathrm{H}$ NMR $\left(300 \mathrm{MHz}, \mathrm{CDCl}_{3}\right) \delta 8.21(\mathrm{~s}, 1 \mathrm{H}), 7.61(\mathrm{~d}, J=$ $8.0 \mathrm{~Hz}, 1 \mathrm{H}), 7.40(\mathrm{~d}, J=8.1 \mathrm{~Hz}, 1 \mathrm{H}), 7.25-7.19(\mathrm{~m}, 1 \mathrm{H}), 7.17-7.09$ (m, 2H), 6.42 $(\mathrm{s}, 2 \mathrm{H}), 5.65(\mathrm{~d}, J=1.4 \mathrm{~Hz}, 1 \mathrm{H}), 5.52(\mathrm{~d}, J=1.4 \mathrm{~Hz}, 1 \mathrm{H}), 3.92(\mathrm{~s}, 6 \mathrm{H}) ;{ }^{13} \mathrm{C} \mathrm{NMR}$ $\left(101 \mathrm{MHz} \mathrm{CDCl}_{3}\right) \delta 163.3,162.3,155.7,141.5,136.5,124.4,122.5,120.5,120.3$, 113.9, 111.4, 102.0, 100.6, 53.7; HR-MS (ESI) $m / z$ : calcd for $\mathrm{C}_{16} \mathrm{H}_{18} \mathrm{NO}_{4}[\mathrm{M}+\mathrm{H}]^{+}$ 281.1285, found 281.1286.

4.1.8.6 3-(1-(2,6-Dimethoxypyridin-4-yl)vinyl)-6-methoxy-1H-indole (16b).

Yield 72.8\%, yellow oil; ${ }^{1} \mathrm{H}$ NMR $\left(300 \mathrm{MHz}, \mathrm{CDCl}_{3}\right) \delta 8.09(\mathrm{~s}, 1 \mathrm{H}), 7.47(\mathrm{~d}, J=$ $8.8 \mathrm{~Hz}, 1 \mathrm{H}), 7.01(\mathrm{~d}, J=2.5 \mathrm{~Hz}, 1 \mathrm{H}), 6.88(\mathrm{~d}, J=2.4 \mathrm{~Hz}, 1 \mathrm{H}), 6.80(\mathrm{dd}, J=8.8,2.3$ Hz, 1H), 6.41 (s, 2H), 5.62 (d, $J=1.4 \mathrm{~Hz}, 1 \mathrm{H}), 5.47$ (d, $J=1.4 \mathrm{~Hz}, 1 \mathrm{H}), 3.92(\mathrm{~s}, 6 \mathrm{H})$, $3.85(\mathrm{~s}, 3 \mathrm{H}) ;{ }^{13} \mathrm{C} \mathrm{NMR}\left(75 \mathrm{MHz}, \mathrm{CDCl}_{3}\right) \delta 163.3,162.3,123.3,121.1,120.4,116.6$, 115.9, 113.4, 110.2, 109.1, 100.6, 98.9, 94.8, 55.7, 53.6; HR-MS (ESI) $\mathrm{m} / \mathrm{z}$ : calcd for $\mathrm{C}_{18} \mathrm{H}_{19} \mathrm{~N}_{2} \mathrm{O}_{3}[\mathrm{M}+\mathrm{H}]^{+}$311.1390, found 311.1391.

4.1.8.7 4-(1-(2,6-Dimethoxypyridin-4-yl)vinyl)-1H-indole (16c).

Yield 56.51\%, green oil; ${ }^{1} \mathrm{H}$ NMR (300 MHz, $\left.\mathrm{CDCl}_{3}\right) \delta 8.20(\mathrm{~s}, 1 \mathrm{H}), 7.38(\mathrm{~d}, J=8.1$ $\mathrm{Hz}, 1 \mathrm{H}), 7.24-7.10(\mathrm{~m}, 2 \mathrm{H}), 7.04$ (d, J=7.2 Hz, 1H), 6.31 (s, 2H), 6.27 (s, 1H), 5.81 $(\mathrm{d}, 1 \mathrm{H}), 5.62(\mathrm{~d}, 1 \mathrm{H}), 3.89(\mathrm{~s}, 6 \mathrm{H}) ;{ }^{13} \mathrm{C} \mathrm{NMR}\left(75 \mathrm{MHz}, \mathrm{CDCl}_{3}\right) \delta 163.4,154.9,147.5$, 136.0, 132.9, 126.7, 124.1, 121.8, 120.6, 117.5, 110.9, 102.5, 100.2, 53.6; HR-MS (ESI) $m / z$ : calcd for $\mathrm{C}_{17} \mathrm{H}_{17} \mathrm{~N}_{2} \mathrm{O}_{2}[\mathrm{M}+\mathrm{H}]^{+} 281.1285$, found 281.1286 .

\subsubsection{5-(1-(2,6-Dimethoxypyridin-4-yl)vinyl)-1H-indole (16d).}

Yield 67.72\%, colorless oil; ${ }^{1} \mathrm{H}$ NMR $\left(300 \mathrm{MHz} \mathrm{CDCl}_{3}\right) \delta 8.14(\mathrm{~s}, 1 \mathrm{H}), 7.52(\mathrm{~d}, J$ $=1.6 \mathrm{~Hz}, 1 \mathrm{H}), 7.28(\mathrm{~d}, J=8.5 \mathrm{~Hz}, 1 \mathrm{H}), 7.16(\mathrm{t}, J=2.8 \mathrm{~Hz}, 1 \mathrm{H}), 7.10(\mathrm{dd}, J=8.4,1.7$ $\mathrm{Hz}, 1 \mathrm{H}), 6.47(\mathrm{~d}, J=2.7 \mathrm{~Hz}, 1 \mathrm{H}), 6.27(\mathrm{~s}, 2 \mathrm{H}), 5.46(\mathrm{~d}, J=1.2 \mathrm{~Hz}, 1 \mathrm{H}), 5.43(\mathrm{~s}, 1 \mathrm{H})$, $3.85(\mathrm{~s}, 6 \mathrm{H}) ;{ }^{13} \mathrm{C}$ NMR $\left(75 \mathrm{MHz}, \mathrm{CDCl}_{3}\right) \delta 163.3,155.7,149.2,135.6,132.1,127.8$, 
124.8, 122.6, 120.6, 114.7, 110.7, 103.0, 100.9, 53.6; HR-MS (ESI) $\mathrm{m} / \mathrm{z}$ : calcd for $\mathrm{C}_{17} \mathrm{H}_{17} \mathrm{~N}_{2} \mathrm{O}_{2}[\mathrm{M}+\mathrm{H}]^{+}$281.1285, found 281.1289.

\subsubsection{The synthesis of target compounds 17a-d.}

To a solution of intermediates 16a-d (1 eq.) in DMF, NaH (1.5 eq.) was added. After stirring for $10 \mathrm{~min}$ at $0{ }^{\circ} \mathrm{C}, \mathrm{CH}_{3} \mathrm{I}$ (1.5 eq.) was added dropwise, then the reaction mixture was warmed to room temperature. After stirring for $2 \mathrm{~h}$ at room temperature, the reaction was quenched with water, extracted with EA, washed with water $(3 \times 50$ $\mathrm{mL}$ ), and the organic layers were then washed with brine, dried over anhydrous $\mathrm{Na}_{2} \mathrm{SO}_{4}$, and concentrated in vacuo. The crude product was purified by column chromatography with petroleum/ethyl acetate to give $\mathbf{1 7 a - d . ~}$

4.1.9.1 3-(1-(2,6-Dimethoxypyridin-4-yl)vinyl)-1-methyl-1H-indole (17a).

Yield 76.19\%, colorless oil; ${ }^{1} \mathrm{H}$ NMR $\left(300 \mathrm{MHz}, \mathrm{CDCl}_{3}\right) \delta 7.66-7.61(\mathrm{~m}, 1 \mathrm{H})$, $7.36-7.31(\mathrm{~m}, 1 \mathrm{H}), 7.25(\mathrm{~d}, J=7.1 \mathrm{~Hz}, 1 \mathrm{H}), 7.17-7.10(\mathrm{~m}, 1 \mathrm{H}), 6.98(\mathrm{~s}, 1 \mathrm{H}), 6.48$ - $6.35(\mathrm{~m}, 2 \mathrm{H}), 5.63(\mathrm{~d}, J=1.4 \mathrm{~Hz}, 1 \mathrm{H}), 5.46(\mathrm{~d}, J=1.5 \mathrm{~Hz}, 1 \mathrm{H}), 3.92(\mathrm{~s}, 6 \mathrm{H}), 3.77(\mathrm{~s}$, $3 \mathrm{H}) ;{ }^{13} \mathrm{C} \mathrm{NMR}\left(75 \mathrm{MHz}, \mathrm{CDCl}_{3}\right) \delta 163.1,162.0,134.0,129.1,126.5,125.6,122.0$, 120.6, 120.1, 109.5, 109.1, 102.0, 100.8, 53.4, 45.5; HR-MS (ESI) $m / z$ : calcd for $\mathrm{C}_{18} \mathrm{H}_{19} \mathrm{~N}_{2} \mathrm{O}_{2}[\mathrm{M}+\mathrm{H}]^{+}$295.1441, found 295.1439.

4.1.9.2 3-(1-(2,6-Dimethoxypyridin-4-yl)vinyl)-6-methoxy-1-methyl-1H-indole (17b).

Yield 16.19\%, white solid; ${ }^{1} \mathrm{H}$ NMR $\left(300 \mathrm{MHz}, \mathrm{CDCl}_{3}\right) \delta 7.49(\mathrm{~d}, J=8.6 \mathrm{~Hz}, 1 \mathrm{H})$, $6.85(\mathrm{~s}, 1 \mathrm{H}), 6.82-6.74(\mathrm{~m}, 2 \mathrm{H}), 6.41(\mathrm{~s}, 2 \mathrm{H}), 5.61-5.56(\mathrm{~m}, 1 \mathrm{H}), 5.40(\mathrm{~d}, J=1.5$ $\mathrm{Hz}, 1 \mathrm{H}), 3.92$ (s, 6H), 3.88 (s, 3H), $3.70(\mathrm{~s}, 3 \mathrm{H}) ;{ }^{13} \mathrm{C} \mathrm{NMR}\left(101 \mathrm{MHz}, \mathrm{CDCl}_{3}\right) \delta 163.2$, 156.5, 156.0, 141.6, 138.2, 128.2, 121.3, 120.8, 112.7, 109.7, 100.7, 98.8, 93.0, 55.7, 53.6, 32.9; HR-MS (ESI) $m / z$ : calcd for $\mathrm{C}_{19} \mathrm{H}_{21} \mathrm{~N}_{2} \mathrm{O}_{3}[\mathrm{M}+\mathrm{H}]^{+} 325.1547$, found 325.1544 .

\subsubsection{4-(1-(2,6-Dimethoxypyridin-4-yl)vinyl)-1-methyl-1H-indole (17c).}

Yield 62.57\%, yellow oil; ${ }^{1} \mathrm{H}$ NMR $\left(300 \mathrm{MHz}, \mathrm{CDCl}_{3}\right) \delta 7.32(\mathrm{~d}, J=8.2 \mathrm{~Hz}, 1 \mathrm{H})$, $7.22(\mathrm{t}, J=7.7 \mathrm{~Hz}, 1 \mathrm{H}), 7.03(\mathrm{~d}, J=7.1 \mathrm{~Hz}, 1 \mathrm{H}), 6.99$ (d, $J=3.2 \mathrm{~Hz}, 1 \mathrm{H}), 6.31(\mathrm{~s}$, 2H), $6.20(\mathrm{~d}, J=3.1 \mathrm{~Hz}, 1 \mathrm{H}), 5.80(\mathrm{~s}, 1 \mathrm{H}), 5.65-5.59(\mathrm{~m}, 1 \mathrm{H}), 3.89(\mathrm{~s}, 6 \mathrm{H}), 3.80(\mathrm{~s}$, $3 \mathrm{H}) ;{ }^{13} \mathrm{C} \mathrm{NMR}\left(75 \mathrm{MHz}, \mathrm{CDCl}_{3}\right) \delta 163.3,154.9,147.5,136.9,133.0,128.8,127.3$, 
121.4, 120.1, 117.4, 109.1, 100.9, 100.2, 53.6, 33.0; HR-MS (ESI) $m / z$ : calcd for $\mathrm{C}_{18} \mathrm{H}_{19} \mathrm{~N}_{2} \mathrm{O}_{2}[\mathrm{M}+\mathrm{H}]^{+}$3295.1441, found 295.1444; Purity: 98.19\% (by HPLC).

4.1.9.4 5-(1-(2,6-Dimethoxypyridin-4-yl)vinyl)-1-methyl-1H-indole (17d).

Yield 74.21\%, yellow oil; ${ }^{1} \mathrm{H}$ NMR (300 MHz, $\left.\mathrm{CDCl}_{3}\right) \delta 7.57(\mathrm{~s}, 1 \mathrm{H}), 7.29(\mathrm{~s}, 1 \mathrm{H})$, $7.19(\mathrm{dd}, J=8.5,1.7 \mathrm{~Hz}, 1 \mathrm{H}), 7.07(\mathrm{~d}, J=3.0 \mathrm{~Hz}, 1 \mathrm{H}), 6.46(\mathrm{~d}, J=3.1 \mathrm{~Hz}, 1 \mathrm{H}), 6.33$ $(\mathrm{s}, 2 \mathrm{H}), 5.53(\mathrm{~s}, 1 \mathrm{H}), 5.49(\mathrm{~s}, 1 \mathrm{H}), 3.92(\mathrm{~s}, 6 \mathrm{H}), 3.81(\mathrm{~s}, 3 \mathrm{H}) ;{ }^{13} \mathrm{C} \mathrm{NMR}(75 \mathrm{MHz}$, $\left.\mathrm{CDCl}_{3}\right) \delta 163.3,155.7,149.2,136.5,131.5,129.5,128.3,122.1,120.8,114.7,108.9$, 101.4, 100.9, 53.7, 33.0; HR-MS (ESI) $m / z$ : calcd for $\mathrm{C}_{18} \mathrm{H}_{19} \mathrm{~N}_{2} \mathrm{O}_{2}[\mathrm{M}+\mathrm{H}]^{+} 295.1441$, found 295.1445 .

\subsubsection{The synthesis of target compounds 17e.}

The 16d (80 mg, $0.29 \mathrm{mmol})$ was dissolved in $\mathrm{EtOH}$, and $37 \% \mathrm{HCHO}$ aqueous (2 $\mathrm{mL})$ and $2 \mathrm{M} \mathrm{NaOH}$ aqueous $(2 \mathrm{~mL})$ were added. After stirring for $1 \mathrm{~h}$ at room temperature, the solvent was removed under a vacuum. The residue was extracted with EA $(3 \times 50 \mathrm{~mL})$, and the combined organic layers were then washed with brine, dried over anhydrous $\mathrm{Na}_{2} \mathrm{SO}_{4}$, and concentrated in vacuo to provide the crude product, which was purified by column chromatography with petroleum/ethyl acetate (10: 1 to 3: 1) to give 17e (60 mg, 66.74\%) as a white solid; ${ }^{1} \mathrm{H}$ NMR $\left(300 \mathrm{MHz}, \mathrm{CDCl}_{3}\right) \delta$ $7.57(\mathrm{~s}, 1 \mathrm{H}), 7.44$ (d, $J=8.5 \mathrm{~Hz}, 1 \mathrm{H}), 7.24(\mathrm{~d}, J=1.8 \mathrm{~Hz}, 1 \mathrm{H}), 7.20(\mathrm{~d}, J=3.2 \mathrm{~Hz}$, $1 \mathrm{H}), 6.52(\mathrm{~d}, J=3.2 \mathrm{~Hz}, 1 \mathrm{H}), 6.32(\mathrm{~s}, 2 \mathrm{H}), 5.64(\mathrm{~d}, J=5.0 \mathrm{~Hz}, 2 \mathrm{H}), 5.52(\mathrm{~d}, J=7.0$ $\mathrm{Hz}, 2 \mathrm{H}), 3.91$ (s, 6H); ${ }^{13} \mathrm{C} \mathrm{NMR}\left(75 \mathrm{MHz}, \mathrm{CDCl}_{3}\right) \delta 163.3,155.5,148.9,135.5,132.6$, 129.2, 128.0, 122.7, 121.0, 115.0, 109.3, 103.3, 100.8, 69.9, 53.7; HR-MS (ESI) $\mathrm{m} / z$ : calcd for $\mathrm{C}_{18} \mathrm{H}_{19} \mathrm{~N}_{2} \mathrm{O}_{3}[\mathrm{M}+\mathrm{H}]^{+}$311.1390, found 311.1395.

\subsubsection{The synthesis of target compound $\mathbf{1 7 f}$.}

Compound 15d (60 mg, $0.21 \mathrm{mmol}$ ) was dissolved in $5 \mathrm{~mL}$ EtOH, $\mathrm{Pd} / \mathrm{C}$ was added. After stirring for $30 \mathrm{~min}$, the solution was collected by filtration, concentrated under a vacuum to obtain crude product, which was purified by column chromatography with petroleum/ethyl acetate (15: 1) to give compound $\mathbf{1 7 f}(50 \mathrm{mg}, 82.75 \%)$ as a white solid; ${ }^{1} \mathrm{H}$ NMR $\left(300 \mathrm{MHz}, \mathrm{CDCl}_{3}\right) \delta 6.78(\mathrm{~s}, 1 \mathrm{H}), 6.75(\mathrm{~s}, 1 \mathrm{H}), 6.69(\mathrm{~d}, J=8.3 \mathrm{~Hz}$, $1 \mathrm{H}), 6.21-6.13(\mathrm{~m}, 2 \mathrm{H}), 5.60-5.53(\mathrm{~m}, 1 \mathrm{H}), 3.87(\mathrm{~s}, 6 \mathrm{H}), 3.86(\mathrm{~s}, 3 \mathrm{H}), 1.58-1.51$ $(\mathrm{m}, 3 \mathrm{H}) ;{ }^{13} \mathrm{C} \mathrm{NMR}\left(75 \mathrm{MHz}, \mathrm{CDCl}_{3}\right) \delta 163.3,161.1,145.5,145.2,138.1,118.9,113.9$, 
110.6, 100.2, 56.0, 53.5, 43.8, 21.1; HR-MS (ESI) $m / z$ : calcd for $\mathrm{C}_{16} \mathrm{H}_{20} \mathrm{NO}_{4}[\mathrm{M}+\mathrm{H}]^{+}$ 290.1387, found 290.1386 .

\subsubsection{The synthesis of intermediates 18a-e.}

To a solution of intermediate $\mathbf{1 0}$ or $\mathbf{1 1}(300 \mathrm{mg})$ in $2 \mathrm{~mL} \mathrm{EtOH}$ in sealed tube was added various amines (10 eq.). The mixture was stirred at $150{ }^{\circ} \mathrm{C}$ for $12-24 \mathrm{~h}$. Then, the mixture was concentrated in vacuo to afford the crude products, which were purified by column chromatography with petroleum/ethyl acetate to give 18a-e as yellow solids.

\subsubsection{The synthesis of target compounds 20a-e and 23.}

The target compounds $\mathbf{2 0 a - e}$ and $\mathbf{2 3}$ were prepared using the same procedures of $15 d$ in moderate yields.

4.1.23.1 5-(1-(2-Chloro-6-(methylamino)pyridin-4-yl)vinyl)-2-methoxyphenol (20a).

Yield 69.13\%, white solid; ${ }^{1} \mathrm{H}$ NMR $\left(300 \mathrm{MHz}, \mathrm{CDCl}_{3}\right) \delta 6.92(\mathrm{~d}, J=1.9 \mathrm{~Hz}, 1 \mathrm{H})$, $6.84-6.75(\mathrm{~m}, 2 \mathrm{H}), 6.55(\mathrm{~d}, J=1.1 \mathrm{~Hz}, 1 \mathrm{H}), 6.19(\mathrm{~d}, J=1.1 \mathrm{~Hz}, 1 \mathrm{H}), 5.73(\mathrm{~s}, 1 \mathrm{H})$, $5.48(\mathrm{~d}, J=1.0 \mathrm{~Hz}, 1 \mathrm{H}), 5.42(\mathrm{~d}, J=1.0 \mathrm{~Hz}, 1 \mathrm{H}), 4.77(\mathrm{~d}, J=5.4 \mathrm{~Hz}, 1 \mathrm{H}), 3.91(\mathrm{~s}$, 3H), $2.89(\mathrm{~d}, J=5.2 \mathrm{~Hz}, 3 \mathrm{H}) ;{ }^{13} \mathrm{C} \mathrm{NMR}\left(75 \mathrm{MHz}, \mathrm{CDCl}_{3}\right) \delta 159.7,153.5,149.5$, 147.2 , 146.7, 145.4, 133.0, 120.1, 115.4, 114.3, 111.7, 110.3, 103.3, 56.0, 29.2; HR-MS (ESI) $m / z$ : calcd for $\mathrm{C}_{15} \mathrm{H}_{16} \mathrm{ClN}_{2} \mathrm{O}_{2}[\mathrm{M}+\mathrm{H}]^{+}$291.0895, found 291.0898; Purity: $100.00 \%$ (by HPLC).

4.1.23.2 5-(1-(2,6-Di(pyrrolidin-1-yl)pyridin-4-yl)vinyl)-2-methoxyphenol (20b).

Yield 67.28\%, white solid; ${ }^{1} \mathrm{H}$ NMR $\left(300 \mathrm{MHz}, \mathrm{CDCl}_{3}\right) \delta 7.25(\mathrm{~d}, J=1.8 \mathrm{~Hz}, 1 \mathrm{H})$, $7.03(\mathrm{~d}, J=2.2 \mathrm{~Hz}, 1 \mathrm{H}), 6.90-6.85(\mathrm{~m}, 1 \mathrm{H}), 6.78-6.73(\mathrm{~m}, 1 \mathrm{H}), 5.58(\mathrm{~s}, 2 \mathrm{H}), 5.40$ $(\mathrm{d}, J=1.6 \mathrm{~Hz}, 1 \mathrm{H}), 5.36(\mathrm{~d}, J=1.8 \mathrm{~Hz}, 1 \mathrm{H}), 3.89(\mathrm{~d}, J=1.7 \mathrm{~Hz}, 3 \mathrm{H}), 3.41(\mathrm{~d}, J=6.5$ $\mathrm{Hz}, 8 \mathrm{H}), 1.92(\mathrm{q}, J=4.2 \mathrm{~Hz}, 8 \mathrm{H}) ;{ }^{13} \mathrm{C} \mathrm{NMR}\left(75 \mathrm{MHz}, \mathrm{CDCl}_{3}\right) \delta 156.9,151.6,149.7$, 146.3, 145.1, 134.3, 120.1, 114.2, 112.9, 110.0, 93.7, 56.0, 46.5, 25.5; HR-MS (ESI) $m / z$ : calcd for $\mathrm{C}_{22} \mathrm{H}_{28} \mathrm{~N}_{3} \mathrm{O}_{2}[\mathrm{M}+\mathrm{H}]^{+} 366.2176$, found 366.2182.

4.1.23.3 5-(1-(2-Chloro-6-(dimethylamino)pyridin-4-yl)vinyl)-2-methoxyphenol (20c).

Yield 57.97\%, offwhite solid; ${ }^{1} \mathrm{H}$ NMR $\left(400 \mathrm{MHz}, \mathrm{CDCl}_{3}\right) \delta 6.93(\mathrm{~d}, J=1.9 \mathrm{~Hz}$, 1H), $6.79(\mathrm{~d}, J=3.1 \mathrm{~Hz}, 1 \mathrm{H}), 6.49(\mathrm{~d}, J=1.1 \mathrm{~Hz}, 1 \mathrm{H}), 6.29$ (d, $J=1.1 \mathrm{~Hz}, 1 \mathrm{H}), 5.60$ (s, 1H), $5.47(\mathrm{~d}, J=1.1 \mathrm{~Hz}, 1 \mathrm{H}), 5.40(\mathrm{~d}, J=1.1 \mathrm{~Hz}, 1 \mathrm{H}), 3.91(\mathrm{~s}, 3 \mathrm{H}), 3.06(\mathrm{~s}, 6 \mathrm{H})$; 
${ }^{13} \mathrm{C}$ NMR $\left(75 \mathrm{MHz}, \mathrm{CDCl}_{3}\right) \delta 159.2,153.1,149.4,147.6,146.6,145.3,133.2,120.0$, $115.1,114.2,110.5,110.3,103.4,56.0,38.1$; HR-MS (ESI) $m / z$ : calcd for $\mathrm{C}_{16} \mathrm{H}_{18} \mathrm{ClN}_{2} \mathrm{O}_{2}[\mathrm{M}+\mathrm{H}]^{+} 305.1051$, found 305.1051 ; Purity: $98.54 \%$ (by HPLC).

4.1.23.4 5-(1-(2,6-Dimorpholinopyridin-4-yl)vinyl)-2-methoxyphenol (20d).

Yield 61.05\%, white solid; ${ }^{1} \mathrm{H}$ NMR $\left(400 \mathrm{MHz}, \mathrm{CDCl}_{3}\right) \delta 6.98(\mathrm{~d}, J=2.0 \mathrm{~Hz}, 1 \mathrm{H})$, $6.84(\mathrm{~d}, J=2.0 \mathrm{~Hz}, 1 \mathrm{H}), 6.81(\mathrm{~d}, J=8.4 \mathrm{~Hz}, 1 \mathrm{H}), 6.00(\mathrm{~s}, 2 \mathrm{H}), 5.64(\mathrm{~s}, 1 \mathrm{H}), 5.46(\mathrm{~d}, J$ $=1.3 \mathrm{~Hz}, 1 \mathrm{H}), 5.37(\mathrm{~d}, J=1.3 \mathrm{~Hz}, 1 \mathrm{H}), 3.93(\mathrm{~s}, 3 \mathrm{H}), 3.84-3.80(\mathrm{~m}, 8 \mathrm{H}), 3.50-3.45$ $(\mathrm{m}, 8 \mathrm{H}) ;{ }^{13} \mathrm{C}$ NMR $\left(75 \mathrm{MHz}, \mathrm{CDCl}_{3}\right) \delta 158.5,153.0,149.2,146.5,145.3,133.8$, 119.9, 114.2, 113.8, 110.2, 96.7, 66.9, 56.0, 45.7; HR-MS (ESI) $\mathrm{m} / \mathrm{z}$ : calcd for $\mathrm{C}_{22} \mathrm{H}_{28} \mathrm{~N}_{3} \mathrm{O}_{4}[\mathrm{M}+\mathrm{H}]^{+}$398.2074, found 398.2076.

4.1.23.5 5-(1-(2-Chloro-6-(piperazin-1-yl)pyridin-4-yl)vinyl)-2-methoxyphenol (20e).

Yield 23.57\%, white solid; ${ }^{1} \mathrm{H}$ NMR $\left(300 \mathrm{MHz}\right.$, Methanol- $\left.d_{4}\right) \delta 6.90(\mathrm{~d}, J=8.1 \mathrm{~Hz}$, 1H), 6.75 (d, $J=2.1 \mathrm{~Hz}, 2 \mathrm{H}), 6.58(\mathrm{~d}, J=7.0 \mathrm{~Hz}, 2 \mathrm{H}), 5.49$ (s, 1H), 5.44 (s, 1H), 3.87 (s, 3H), $3.58(\mathrm{t}, J=5.1 \mathrm{~Hz}, 4 \mathrm{H}), 3.03(\mathrm{t}, J=5.1 \mathrm{~Hz}, 4 \mathrm{H}) ;{ }^{13} \mathrm{C} \mathrm{NMR}\left(101 \mathrm{MHz}, \mathrm{CDCl}_{3}\right)$ $\delta 158.5,154.0,149.7,147.2,146.8,145.5,132.9,120.0,115.7,114.2,113.3,110.4$, 104.6, 56.0, 44.1, 43.9; HR-MS (ESI) $m / z$ : calcd for $\mathrm{C}_{18} \mathrm{H}_{21} \mathrm{ClN}_{3} \mathrm{O}_{2}[\mathrm{M}+\mathrm{H}]^{+} 346.1317$, found 346.1320 .

\subsubsection{2-Methoxy-5-(1-(pyridin-4-yl)vinyl)phenol (23).}

Yield 39.7\%, white solid; ${ }^{1} \mathrm{H}$ NMR $\left(400 \mathrm{MHz}, \mathrm{CDCl}_{3}\right) \delta 8.51(\mathrm{~d}, J=6.2 \mathrm{~Hz}, 2 \mathrm{H})$, $7.26(\mathrm{t}, J=1.3 \mathrm{~Hz}, 1 \mathrm{H}), 7.25(\mathrm{~d}, J=1.7 \mathrm{~Hz}, 1 \mathrm{H}), 6.85(\mathrm{~d}, J=8.9 \mathrm{~Hz}, 1 \mathrm{H}), 6.83-6.80$ $(\mathrm{m}, 2 \mathrm{H}), 5.55(\mathrm{~d}, J=0.9 \mathrm{~Hz}, 1 \mathrm{H}), 5.47(\mathrm{~d}, J=0.9 \mathrm{~Hz}, 1 \mathrm{H}), 3.91(\mathrm{~s}, 3 \mathrm{H}) ;{ }^{13} \mathrm{C} \mathrm{NMR}(75$ $\left.\mathrm{MHz}, \mathrm{CDCl}_{3}\right) \delta 149.8,149.1,147.4,147.2,146.0,132.7,123.3,119.6,115.8,114.7$, 110.8, 56.0; HR-MS (ESI) $m / z$ : calcd for $\mathrm{C}_{14} \mathrm{H}_{14} \mathrm{NO}_{2}[\mathrm{M}+\mathrm{H}]^{+} 228.1019$, found 228.1022 .

\subsubsection{The synthesis of target compounds $27 \boldsymbol{a}-\boldsymbol{b}$.}

To a solution of intermediate $26(150 \mathrm{mg}, 0.33 \mathrm{mmol})$ in $2 \mathrm{~mL}$ dioxane at sealed tube under $\mathrm{N}_{2}$ atmosphere, 4-chloro-2-methylpyridine (42.65 $\mathrm{mg}, 0.33 \mathrm{mmol}$ ) or 4-chloro-2,6-dimethylpyridine (47.34 mg, $0.33 \mathrm{mmol})$, dppf (18.54 mg, $0.033 \mathrm{mmol})$, $\mathrm{Pd}\left(\mathrm{CH}_{3} \mathrm{CN}\right)_{2} \mathrm{Cl}_{2}(8.67 \mathrm{mg}, 0.033 \mathrm{mmol})$ and $\mathrm{Cs}_{2} \mathrm{CO}_{3}(272.33 \mathrm{mg}, 0.84 \mathrm{mmol})$ were added. The post-treatment of $\mathbf{2 7 a - b}$ was similar to that of $\mathbf{1 5 d}$. The target compounds 
27a-b were obtain in low yields.

4.1.24.1 2-Methoxy-5-(1-(2-methylpyridin-4-yl)vinyl)phenol (27a).

Yield 19.7\%, white solid; ${ }^{1} \mathrm{H}$ NMR (400 MHz, $\left.\mathrm{CDCl}_{3}\right) \delta 8.39(\mathrm{~d}, J=5.2 \mathrm{~Hz}, 1 \mathrm{H})$, $7.10(\mathrm{~d}, J=1.6 \mathrm{~Hz}, 1 \mathrm{H}), 7.06(\mathrm{dd}, J=5.3,1.7 \mathrm{~Hz}, 1 \mathrm{H}), 6.84(\mathrm{~d}, J=1.9 \mathrm{~Hz}, 2 \mathrm{H}), 6.79$ $(\mathrm{dd}, J=1.7,0.8 \mathrm{~Hz}, 1 \mathrm{H}), 5.53(\mathrm{~d}, J=1.0 \mathrm{~Hz}, 1 \mathrm{H}), 5.43(\mathrm{~d}, J=0.9 \mathrm{~Hz}, 1 \mathrm{H}), 3.92$ (s, 3H), $2.53(\mathrm{~s}, 3 \mathrm{H}) ;{ }^{13} \mathrm{C} \mathrm{NMR}\left(75 \mathrm{MHz}, \mathrm{CDCl}_{3}\right) \delta 158.1,150.0,148.5,147.4,147.2$, 145.9, 132.9, 122.8, 120.5, 119.6, 115.5, 114.5, 110.7, 56.0, 24.1; HR-MS (ESI) $m / z$ : calcd for $\mathrm{C}_{15} \mathrm{H}_{16} \mathrm{NO}_{2}[\mathrm{M}+\mathrm{H}]^{+} 242.1172$, found 242.1172 .

\subsubsection{5-(1-(2,6-Dimethylpyridin-4-yl)vinyl)-2-methoxyphenol (27b).}

Yield 25.72\%, white solid; ${ }^{1} \mathrm{H}$ NMR (400 MHz, $\left.\mathrm{CDCl}_{3}\right) \delta 8.44(\mathrm{~s}, 1 \mathrm{H}), 6.90(\mathrm{~s}, 2 \mathrm{H})$, $6.88(\mathrm{~d}, J=1.9 \mathrm{~Hz}, 1 \mathrm{H}), 6.87(\mathrm{~s}, 1 \mathrm{H}), 6.67(\mathrm{~d}, J=1.9 \mathrm{~Hz}, 1 \mathrm{H}), 5.51(\mathrm{~d}, J=1.0 \mathrm{~Hz}$, 1H), $5.38(\mathrm{~d}, J=1.1 \mathrm{~Hz}, 1 \mathrm{H}), 3.93(\mathrm{~s}, 3 \mathrm{H}), 2.49$ (s, 6H); ${ }^{13} \mathrm{C} \mathrm{NMR}\left(75 \mathrm{MHz}, \mathrm{CDCl}_{3}\right)$ $\delta 157.0,150.8,147.8,147.5,146.4,132.6,120.3,118.9,115.1,114.2,111.1,55.9$, 23.5; HR-MS (ESI) $m / z$ : calcd for $\mathrm{C}_{16} \mathrm{H}_{18} \mathrm{NO}_{2}[\mathrm{M}+\mathrm{H}]^{+} 256.1332$, found 256.1332 .

\subsubsection{The synthesis of intermediate 29.}

The $1 H$-indole-5-carboxylic acid $(1.5 \mathrm{~g}, 9.31 \mathrm{mmol})$ was dissolved in THF under Ar atmosphere and $\mathrm{CH}_{3} \mathrm{Li}(1.5 \mathrm{M}, 20.48 \mathrm{~mL}, 30.71 \mathrm{mmol})$ was added dropwise at $0{ }^{\circ} \mathrm{C}$ After stirring for $12 \mathrm{~h}$, the reaction was quenched with water, extracted with EA ( $3 \times$ $150 \mathrm{~mL}$ ), and the combined organic layers were then washed with brine, dried over anhydrous $\mathrm{Na}_{2} \mathrm{SO}_{4}$, and concentrated in vacuo to provide the crude product, which was purified by column chromatography with petroleum/ethyl acetate (4:1) to give 29 $(1.30 \mathrm{~g}, 87.97 \%)$ as a yellow oil. The spectra data were consistent with the literature [29].

\subsubsection{The synthesis of target compounds $\mathbf{3 2 a - b}$.}

The target compounds 32a-b were prepared using the same procedures of 15a-c in moderate yields.

4.1.26.1 1-Methyl-5-(1-(2-methylpyridin-4-yl)vinyl)-1H-indole (32a).

Yield 62.76\%, yellow solid; ${ }^{1} \mathrm{H}$ NMR $\left(400 \mathrm{MHz}, \mathrm{CDCl}_{3}\right) \delta 8.44(\mathrm{t}, J=4.1 \mathrm{~Hz}, 1 \mathrm{H})$, $7.54(\mathrm{~d}, J=1.8 \mathrm{~Hz}, 1 \mathrm{H}), 7.29(\mathrm{dd}, J=8.4,2.7 \mathrm{~Hz}, 1 \mathrm{H}), 7.17(\mathrm{dd}, J=8.4,1.8 \mathrm{~Hz}, 1 \mathrm{H})$, $7.14(\mathrm{~s}, 1 \mathrm{H}), 7.10(\mathrm{dd}, J=5.2,1.8 \mathrm{~Hz}, 1 \mathrm{H}), 7.07(\mathrm{t}, J=2.9 \mathrm{~Hz}, 1 \mathrm{H}), 6.47(\mathrm{~d}, J=3.0$ 
$\mathrm{Hz}, 1 \mathrm{H}), 5.56$ (s, 1H), 5.51 (s, 1H), 3.81 (s, 3H), 2.54 (s, 3H); ${ }^{13} \mathrm{C}$ NMR (101 MHz, $\left.\mathrm{CDCl}_{3}\right) \delta 158.3,150.4,149.2,149.1,136.6,131.5,129.6,128.4,122.6,122.1,120.8$, 120.3 115.1, 109.0, 101.4, 33.0, 24.5; HR-MS (ESI) $m / z$ : calcd for $\mathrm{C}_{17} \mathrm{H}_{17} \mathrm{~N}_{2}[\mathrm{M}+\mathrm{H}]^{+}$ 249.1386, found 256.1388; Purity: 97.21\% (by HPLC).

4.1.26.2 5-(1-(2,6-Dimethylpyridin-4-yl)vinyl)-1-methyl-1H-indole (32b).

Yield 67.59\%, yellow solid; ${ }^{1} \mathrm{H}$ NMR $\left(300 \mathrm{MHz}, \mathrm{CDCl}_{3}\right) \delta 7.55(\mathrm{~s}, 1 \mathrm{H}), 7.28(\mathrm{~s}$, 1H), $7.18(\mathrm{~s}, 1 \mathrm{H}), 7.08(\mathrm{~s}, 1 \mathrm{H}), 6.96(\mathrm{~s}, 2 \mathrm{H}), 6.48(\mathrm{~s}, 1 \mathrm{H}), 5.55(\mathrm{~s}, 1 \mathrm{H}), 5.52-5.46(\mathrm{~m}$,

1H), $3.82(\mathrm{~s}, 3 \mathrm{H}), 2.52(\mathrm{~s}, 6 \mathrm{H}) ;{ }^{13} \mathrm{C} \mathrm{NMR}\left(101 \mathrm{MHz}, \mathrm{CDCl}_{3}\right) \delta 157.6,150.7,149.4$, $136.5,131.7,129.6,128.4,122.1,120.8,119.8,114.9$, 109.0, 101.4, 33.0, 24.5; HR-MS (ESI) $m / z$ : calcd for $\mathrm{C}_{18} \mathrm{H}_{19} \mathrm{~N}_{2}[\mathrm{M}+\mathrm{H}]^{+}$263.1543, found 263.1544; Purity: 99.35\% (by HPLC).

\subsection{Pharmacology}

\subsubsection{Anti-proliferative studies}

All cell lines were purchased from Nanjing KeyGen Biotech Co. Ltd. (Nanjing, China). The 3-(4,5-dimethyl-2-thiazolyl)-2,5-diphenyl-2-H-tetrazolium bromide (MTT) assay was performed to evaluate the anti-proliferative activity of the compounds. The cell lines were cultured in 96-well cell culture plate containing growth medium at $37{ }^{\circ} \mathrm{C}$ in a humidified $5 \% \mathrm{CO}_{2}$ incubator for $24 \mathrm{~h}$. Then, the cells were treated with $100 \mu \mathrm{L}$ tested compounds at 9 different final concentration. After 72 h of incubation, $10 \mu \mathrm{L}$ MTT was added to 96-well cell culture plate and incubated for 1-2 $\mathrm{h}$ before the absorbance was recorded at $450 \mathrm{~nm}$ with a spectrophotometric plate reader. The dose-response curves were plotted with Graph Prism software, and the $\mathrm{IC}_{50}$ values were calculated using the Graph Prism software from polynomial curves. All experiments were measured at least three times.

\subsubsection{Analysis of tubulin polymerization in vitro and competitive inhibition assays}

An in vitro assay for monitoring the time-dependent polymerization of tubulin to microtubules was performed. An amount of $2 \mathrm{mg} / \mathrm{mL}$ tubulin (Cytoskeleton) was suspended with PEM buffer containing $80 \mathrm{mM}$ piperazine-N,N'-bis(2-ethanesulfonic acid) sequisodium salt PIPES ( $\mathrm{pH}$ 6.9), $0.5 \mathrm{mM}$ EGTA, $2 \mathrm{mM} \mathrm{MgCl}_{2}$, and $15 \%$ 
glycerol. Then the mixture was preincubated with tested compounds or vehicle DMSO on ice for 5 min. PEG containing GTP was added to the final concentration of $3 \mathrm{mg} / \mathrm{mL}$ before detecting the tubulin polymerization reaction. The OD values at 340 nm were determined through Berthold LB941 microplate multi-function microplate reader.

The radiolabeled $\left[{ }^{3} \mathrm{H}\right]$ colchicine competitive scintillation approximation (SPA) was used to evaluate the competitive binding activity of the inhibitors. The $0.08 \mu \mathrm{M}\left[{ }^{3} \mathrm{H}\right]$ colchicine, the tested compounds with different concentration and $0.5 \mu \mathrm{g}$ tubulin were added to the $100 \mu \mathrm{L}$ buffer containing $80 \mathrm{mM}$ PIPES (pH 6.9), $0.5 \mathrm{mM}$ EGTA, $2 \mathrm{mM}$ $\mathrm{MgCl}_{2}$, and $15 \%$ glycerol. After incubation for $2 \mathrm{~h}$, streptavidin-labeled SPA beads $(80 \mu \mathrm{g})$ were added to mixture and the sample was counted using a TopCountTM Microplate Scintillation Counter.

\subsubsection{Cell cycle analysis}

Exponentially growing K562 cancer cells were incubated with 20a at concentrations of 5, 10, and $20 \mathrm{nM}$ and isoCA-4 at 3, 6, and $12 \mathrm{nM}$ in 6-well culture cell plates for $72 \mathrm{~h}$, with $1 \%$ DMSO as vehicle control group. After collection using $0.25 \%$ trypsin, the cells were washed twice with PBS buffer. The collected cells were fixed by adding $70 \%$ ethanol at $4{ }^{\circ} \mathrm{C}$ for $12 \mathrm{~h}$. After being washed with PBS, $100 \mu \mathrm{L}$ RNase was added, then $400 \mu \mathrm{L}$ PI was used to stain for $30 \mathrm{~min}$. The cell cycle distribution was examined by a FACScan flow cytometer (BectoneDickinson, USA), and the data were analyzed using the Modfit program (BectoneDickinson, USA).

\subsubsection{Apoptosis assay.}

Annexin V-FITC/PI dual staining assay was performed to determine the cells apoptosis. K562 cells were incubated with 5, 10, and $20 \mathrm{nM}$ compound 20a in 6-well cell culture plates for $72 \mathrm{~h}$. The cells were washed twice in PBS, then $500 \mu \mathrm{L}$ binding buffer suspended cells were added. The cells were stained with $5 \mu \mathrm{L}$ Annexin V-FITC and PI. Then the cells were incubated at room temperature for $20 \mathrm{~min}$ without light exposure. Apoptosis was analyzed using a FACS Calibur flow cytometer (Bectone Dickinson, San Jose, CA, USA). 


\subsubsection{Immunofluorescence staining.}

After being cultured in 6-well cell culture plates, K562 cells were treated with 5, 10, and $20 \mathrm{nM}$ compound 20a or vehicle control 1\% DMSO. After being fixed with $4 \%$ paraformaldehyde, the cells were penetrated with PBS for three times and blocked with $50-100 \mu \mathrm{L}$ goat serum albumin at room temperature for $20 \mathrm{~min}$. Then they were incubated with rabbits anti- $\alpha$-tubulin antibody (UK, Abcam, ab6046) for $2 \mathrm{~h}$ at $37{ }^{\circ} \mathrm{C}$ and then incubated with goat anti-rabbit IgG-TRITC (Nanjing KeyGen Biotech Co. Ltd., China) at $37{ }^{\circ} \mathrm{C}$ for $1 \mathrm{~h}$. After being washed three times by PBS, the cells were counterstain using 4,6-diamidino-2-phenylindole (DAPI). Cells were finally visualized under a fluorescence microscope (OLYMPUS, Japan).

\subsubsection{Mitochondrial membrane potential analysis.}

A lipophilic cationic dye, 5, 5', 6, 6'-tetrachloro-1, 1', 3,3 -tetraethylbenzimidazolcarbocyanine (JC-1) was used to monitor the level of MMP in the cells by flow cytometry. K562 cells were seeded in 6-well cell culture plates and cultivated for $24 \mathrm{~h}$, then incubated with 20a at 5, 10 and $20 \mathrm{nM}$ for $24 \mathrm{~h}$. After being washed with PBS buffer, the cells were harvested by centrifugation and resuspended in $500 \mu \mathrm{L} \mathrm{JC}-1$ incubation buffer at $37{ }^{\circ} \mathrm{C}$ for $15-20$ min. After briefly washing, the proportion of red fluorescence intensity was immediately detected and analyzed by flow cytometry (Bectone-Dickinson, San Jose, CA, USA).

\subsubsection{Tube Formation Assay.}

The HUVECs cells were seeded in 6-well plates and cultivated for $24 \mathrm{~h}$, then incubated with 5, 10, and $20 \mathrm{nM}$ 20a. The EC Matrigel matrix was thawed at $4{ }^{\circ} \mathrm{C}$ overnight, and HUVECs suspended in F12K were seeded in 96-well culture plates at a cell density of 50000 cells/well after polymerization of the Matrigel at $37{ }^{\circ} \mathrm{C}$ for 30 min. They were then treated with $20 \mu \mathrm{L}$ different concentrations of $20 \mathbf{a}$ or vehicle for $6 \mathrm{~h}$ at $37{ }^{\circ} \mathrm{C}$. Then, the morphological changes of the cells and tubes formed were observed and photographed under an inverted microscope (OLYMPUS, Japan).

\subsubsection{Wound Healing Assays.}

K562 cells were seeded in 6-well plates and cultivated for $24 \mathrm{~h}$. Scratches were 
made in confluent monolayers using $200 \mu \mathrm{L}$ pipette tips. Then, wounds were washed twice with PBS to remove nonadherent cell debris. The media containing different concentrations $(0,5,10$, and $20 \mathrm{nM})$ of $\mathbf{2 0 a}$ were added to the Petri dishes. Cells which migrated across the wound area were photographed using phase contrast microscopy at 0 and $24 \mathrm{~h}$. The migration distance of cells migrated to the wound area was measured manually.

\subsubsection{In vivo antitumor activity assay.}

Five-week-old male Institute of Cancer Research (ICR) mice were purchased from Shanghai SLAC Laboratory Animals Co. Ltd. A total of $1 \times 10^{6} \mathrm{H} 22$ cells were subcutaneously inoculated into the right flank of ICR mice according to protocols of tumor transplant research, to initiate tumor growth. After incubation for one day, mice were weighted and divided into eight groups at random with eight animals in each group. The groups treated with 20a were administered $15,30 \mathrm{mg} / \mathrm{kg}$ in a vehicle of $10 \% \mathrm{DMF} / 2 \%$ Tween $80 / 88 \%$ saline, respectively. The positive control group was treated with taxol $(6 \mathrm{mg} / \mathrm{kg})$ every 2 days by intravenous injection, while isoCA-4 was administered 15 and $30 \mathrm{mg} / \mathrm{kg}$ in a vehicle of $10 \% \mathrm{DMF} / 2 \%$ Tween 80/88\% saline. The negative control group received a vehicle of $10 \% \mathrm{DMF} / 2 \%$ Tween $80 / 88 \%$ saline through intravenous injection. Treatments of 20a and isoCA-4 were done at a frequency of intravenous injection one dose per day for a total 21 consecutive days while the positive group was treated with taxol one dose per two days. The mice were executed after the treatments and the tumors were excised and weighed. The inhibition rate was calculated as follows: Tumor inhibitory ratio $(\%)=(1$-average tumor weight of treated group/average tumor weight of control group) $\times 100 \%$.

\subsubsection{H\&E staining.}

The Mouse organs (heart, liver, spleen, lung, kidney) were isolated, then which were fixed in $4 \%$ paraformaldehyde and embedded in paraffin using tissue embedding machine. The tissues were sectioned in the vertical plane into $5 \mu \mathrm{m}$-thick. Then, sections were prepared orderly by dewaxing, stainingm and dehydration. After staining in Harris hematoxylin solution, sections were stained in eosin-phloxine 
solution for 1 min and then dehydrated and mounted with neutral resin. The tissue morphology was observed under a microscope.

\subsubsection{Molecular docking study.}

Based on our previous study, the X-ray structure of $\alpha, \beta$-tubulin in complex with CA-4 was downloaded from the Protein Data Bank (PDB code: 5LYJ) [36]. The protein was prepared by the Protein Preparation Wizard module in Schrodinger. The compound 20a, CA-4 and isoCA-4 were prepared by the Ligprep module in Schrodinger Suite, and were minimized by OPLS-2005 force field. The docking procedure was performed by employing Glide extra precision (Glide-XP) in Ligand Docking program in Schrodinger, and the structural image was obtained using PyMOL Molecular Graphics System version 2.7.

\section{Acknowledgments}

This study was supported from the National Natural Science Foundation of China (No. 81673306, 81703348, 81874289, and 81973167), and "Double First-Class" University project CPU2018GY04, CPU2018GY35, China Pharmaceutical University, for financial support.

\section{References}

1. M. Jordan, L. Wilson, Microtubules as a target for anticancer drugs, Nat. Rev. Canc. 4 (2004) 253-265.

2. S. Chaaban, G.J. Brouhard, A microtubule bestiary: structural diversity in tubulin polymers, Mol. Biol. Cell 28 (2017) 2924-2931.

3. A. Muroyama, T. Lechler, Microtubule organization, dynamics and functions in differentiated cells, Development 144 (2017) 3012-3021.

4. C. Dumontet, M. Jordan, Microtubule-binding agents: a dynamic field of cancer therapeutics, Nat. Rev. Drug Discov. 9 (2010) 790-803.

5. S. Banerjee, K.E. Arnst, Y. Wang, G. Kumar, S. Deng, L. Yang, G.B. Li, J. Yang, S.W. White, W. Li, D.D. Miller, Heterocyclic-fused pyrimidines as novel tubulin polymerization inhibitors targeting the colchicine binding site: structural basis and antitumor efficacy, J. Med. Chem. 61 (2018) 1704-1718. 
6. P Chen, Y Zhuang, P Diao, F Yang, S Wu, L Lv, W You, P Zhao, Synthesis, biological evaluation, and molecular docking investigation of 3-amidoindoles as potent tubulin polymerization inhibitors, Eur. J. Med. Chem. 162 (2019) 525-533.

7. Y. Cao, L. Zheng, D. Wang, X. Liang, F. Gao, X. Zhou, Recent advances in microtubule-stabilizing agents, Eur. J. Med. Chem. 143 (2018) 806-828.

8. W. Li, F. Xu, W Shuai, H. Sun, H. Yao, C. Ma, S. Xu, H. Yao, Z. Zhu, D. Yang, Z. Chen, J. $\mathrm{Xu}$, Discovery of novel quinoline-chalcone derivatives as potent antitumor agents with microtubule polymerization inhibitory activity, J. Med. Chem. 62 (2018) 993-1013.

9. W. Li, H. Sun, S. Xu, Z. Zhu, J. Xu, Tubulin inhibitors targeting the colchicine binding site: a perspective of privileged structures, Future Med. Chem. 9 (2017) 1765-1794.

10. F. Naaz, M.R. Haider, S. Shafi, and M.S. Yar, Anti-tubulin agents of natural origin: Targeting taxol, vinca, and colchicine binding domains. Eur. J. Med. Chem. 171 (2019) 310-331.

11. E. Porcù, R. Bortolozzi, G. Basso, G. Viola, Recent advances in vascular disrupting agents in cancer therapy, Future Med. Chem. 6 (2014) 1485-1498.

12. Z. Liu, Y. Liu, Y. Ji, Tubulin colchicine binding site inhibitors as vascular disrupting agents in clinical developments, Curr. Med. Chem. 22 (2015) 1348 1360.

13. Q. Xu, M. Sun, Z. Bai, Y. Wang, Y. Wu, H. Tian, D. Zuo, Q. Guan, K. Bao, Y. Wu, W. Zhang, Design, synthesis and bioevaluation of antitubulin agents carrying diaryl-5,5-fused-heterocycle scaffold, Eur. J. Med. Chem.139 (2017) 242-249.

14. Y. Zhang, B. Li, R. Yan, L. Xia, A. Fan, Y. Chu, L. Wang, Z. Wang, A. Jiang, H. Zhu, A class of novel tubulin polymerization inhibitors exert effective antitumor activity via mitotic catastrophe, Eur. J. Med. Chem. 163 (2019) 896-910.

15. W. Li, Y. Yin, H. Yao, W. Shuai, H. Sun, S. Xu, J. Liu, H. Yao, Z. Zhu, J. Xu, Discovery of novel vinyl sulfone derivatives as anti-tumor agents with microtubule polymerization inhibitory and vascular disrupting activities, Eur. J. Med. Chem. 157 (2018) 1068-1080. 
16. G. R. Pettit, S. B. Singh, M. R. Boyd, E. Hamel, R. K. Pettit, J. M. Schmidt, F. Hogan, Antineoplastic agents. 291. isolation and synthesis of combretastatins A-4, A-5, and A-6, J. Med. Chem. 38 (1995) 1666-1672.

17. S. Aprile, E. Del Grosso, G. C. Tron, G. Grosa, In vitro metabolism study of combretastatin A-4 in rat and human liver microsomes, Drug. Metab. Dispos. 35 (2007) 2252-2261.

18. S. Messaoudi, B. Tréguier, A. Hamze, O. Provot, J. F. Peyrat, J. R. Rodrigo De Losada, J. M. Liu, J. Bignon, J. Wdzieczak-Bakala, S. Thoret, J. Dubois, J. D. Brion, M. Alami, IsoCombretastatins A versus combretastatins A: the forgotten isoCA-4 isomer as a highly promising cytotoxic and antitubulin agent, J. Med. Chem. 52 (2009) 4538-4542.

19. G. Pettit, B. Toki, D. Herald, P. Verdier-Pinard, M. Boyd, E. Hamel, R. Pettit, Antineoplastic Agents. 379. Synthesis of phenstatin phosphate. J. Med. Chem. 41 (1998) 1688-1695.

20. A. Gomtsyan, Heterocycles in drugs and drug discovery. Chem. Heterocycl. Compd. 48 (2012) 7-10.

21. L. D. Pennington, D. T. Moustakas, The necessary nitrogen atom: a versatile high-impact design element for multiparameter optimization. J. Med. Chem. 60 (2017) 3552-3579.

22. M. A. Soussi, O. Provot, G. Bernadat, J. Bignon, D. Desravines, J. Dubois, J. Brion, S. Messaoudi, M. Alami, IsoCombretaQuinazolines: potent cytotoxic agents with antitubulin activity. Chem. Med. Chem, 10 (2015), 1392-1402.

23. I. Khelifi, T. Naret, D. Renko, A. Hamze, G. Bernadat, J. Bignon, C. Lenoir, J. Dubois, J. Brion, O. Provot, M. Alami, Design, synthesis and anticancer properties of isoCombretaquinolines as potent tubulin assembly inhibitors. Eur. J. Med. Chem. 127 (2017) 1025-1034.

24. W. Li., W. Shuai, H. Sun, F. Xu, Y. Bi, J. Xu, S. Xu, Design, synthesis and biological evaluation of quinoline-indole derivatives as anti-tubulin agents targeting the colchicine binding site. Eur. J. Med. Chem. 163(2019), 428-442.

25. F. Xu, W. Li, W. Shuai, L. Yang, Y. Bi, C. Ma, H. Yao, S. Xu, Z. Zhu, J. Xu, 
Design, synthesis and biological evaluation of pyridine-chalcone derivatives as novel microtubule-destabilizing agents. Eur. J. Med. Chem. 173 (2019) 1-14.

26. J. Aziz, G. Frison, M. Gomez, J. Brion, A. Hamze, M. Alami, Copper-catalyzed coupling of $N$-tosylhydrazones with amines: synthesis of fluorene derivatives, ACS catal. 4 (2014) 4498-4503.

27. Y. Tong, X. Zhang, M. Geng, J. Yue, X. Xin, T. Fang, S. Xu, L. Tong, M. Li, C. Zhang, W. Li, L. Lin, J. Ding, Pseudolarix acid B, a new tubulin-binding agent, inhibits angiogenesis by interacting with a novel binding site on tubulin, Mol. Pharmacol. 69 (2006) $1226-1233$.

28. Y. Liu, J. Wang, Y. Ji, G. Zhao, L. Tang, C. Zhang, X. Guo, Z. Liu, Design, synthesis, and biological evaluation of 1-methyl-1,4dihydroindeno[1,2- c]pyrazole analogues as potential anticancer agents targeting tubulin colchicine binding site, J. Med. Chem. 59 (2016) 5341-5355.

29. C. Tian, M. Wang, Z. Han, F. Fang, Z. Zhang, X. Wang, J. Liu, Design, synthesis and biological evaluation of novel 6-substituted pyrrolo $[3,2-d]$ pyrimidine analogues as antifolate antitumor agents, Eur. J. Med. Chem. 138 (2017) 630-643.

30. A. Rovini, A. Savry, D. Braguer, M. Carre, Microtubule-' targeted agents: when mitochondria become essential to chemotherapy, Biochim. Biophys. Acta. 1807 (2011) 679-88.

31. E. Lugli, L. Troiano, A. Cossarizza, Polychromatic analysis of mitochondrial membrane potential using JC-1, Curr. Protoc. Cytom. (2007). Unit7.32.

32. C. Wang, L. Lei, D. Fu, T. Qin, Y. Re, F. Xu, X. Du, H. Gao, S. Sun, T. Yang, X. Zhang, J. Huo,W. Zhao, Z. Zhang, X, Shi, Discovery of chalcone-modified estradiol analogs as antitumour agents that inhibit tumour angiogenesis and epithelial to mesenchymal transition, Eur. J. Med. Chem. 176 (2019) 135-148.

33. S. Banerjee, D. Hwang, W. Li, D. Miller. Current advances of tubulin inhibitors in nanoparticle drug delivery and vascular disruption/angiogenesis, Molecules. 21 (2016) 1468.

34. J. Bauer, M. Margolis, C. Schreiner, C.J. Edgell, J. Azizkhan, E. Lazarowski, R.L. Juliano, In vitro model of angiogenesis using a human endothelium-derived 
permanent cell line: contributions of induced gene expression, G-proteins, and integrins, J. Cell. Physiol. 153 (1992) 437-449.

35. E. Aranda, G. Owen, A semi-quantitative assay to screen for angiogenic compounds and compounds with angiogenic potential using the EA. hy926 endothelial cell line, Biol. Res. 42 (2009) 377-389.

36. R. Gaspari, A.E. Prota, K. Bargstem, A. Cavalli, M.O. Steinmetz, Structural basis of cis- and trans-Combretastatin binding to tubulin, Chem. 2 (2017) 102-113. 